\title{
On a remarkable new species of Tharsis, a Late Jurassic teleostean fish from southern Germany: its morphology and phylogenetic relationships
}

\author{
Gloria Arratia $^{1}$, Hans-Peter Schultze ${ }^{1}$, and Helmut Tischlinger ${ }^{2}$ \\ ${ }^{1}$ Biodiversity Institute, University of Kansas, Dyche Hall, 1345 Jayhawk Blvd, Lawrence, Kansas 66045, USA \\ 2independent researcher: Tannenweg 16, 85134 Stammham, Germany
}

Correspondence: Gloria Arratia (garratia@ku.edu)

Received: 4 September 2018 - Revised: 2 December 2018 - Accepted: 4 December 2018 - Published: 7 January 2019

\begin{abstract}
A complete morphological description, as preservation permits, is provided for a new Late Jurassic fish species (Tharsis elleri) together with a revision and comparison of some morphological features of Tharsis $d u$ bius, one of the most common species from the Solnhofen limestone, southern Germany. An emended diagnosis of the genus Tharsis - now including two species - is presented. The new species is characterized by a combination of morphological characters, such as the presence of a complete sclerotic ring formed by two bones placed anterior and posterior to the eye, a moderately short lower jaw with quadrate-mandibular articulation below the anterior half of the orbit, caudal vertebrae with neural and haemal arches fused to their respective vertebral centrum, and parapophyses fused to their respective centrum. A phylogenetic analysis based on 198 characters and 43 taxa is performed. Following the phylogenetic hypothesis, the sister-group relationship Ascalaboidae plus more advanced teleosts stands above the node of Leptolepis coryphaenoides. Both nodes have strong support among teleosts. The results confirm the inclusion of Ascalabos, Ebertichthys and Tharsis as members of this extinct family. Tharsis elleri $\mathrm{n}$. sp. (LSID urn:lsid:zoobank.org:act:6434E6F5-2DDD-48CFA2B1-827495FE46E6, date: 13 December 2018) is so far restricted to one Upper Jurassic German locality - Wegscheid Quarry near Schernfeld, Eichstätt - whereas Tharsis dubius is known not only from Wegscheid Quarry, but also from different localities in the Upper Jurassic of Bavaria, Germany, and Cerin in France.
\end{abstract}

\section{Introduction}

Late Jurassic fishes of the Solnhofen limestone of Bavaria, southern Germany, have been known for over 500 years and are currently known by 115 (including Ebertichthys) formally described actinopterygian species (Schultze, 2015: table 5). The earliest illustrations showing a fish - which would correspond to what it is currently interpreted as Tharsis dubius (Blainville, 1818) - appeared in the works of Besler (1616), Baier (1757: pl. 3) and Knorr (1755: pl. 23, figs. 2, 3, pl. 26a: figs. 1-4, pl. 28: fig. 2, pl. 29: figs. 2-4; see Tischlinger and Viohl, 2015). A Tharsis specimen is also the oldest known specimen of the Solnhofen limestone, which was collected (Raritätenkabinett zu Ambras; today in the Naturhistorisches Museum, Vienna, Austria) in the first half of the 16th century (Tischlinger and Viohl, 2015: fig. 59). Later, fishes illustrated by Knorr were given scientific names by Blainville (1818) and one of them was named Clupea $\mathrm{du}$ bia for its overall resemblance to the extant clupeiform genus Clupea.

The publication of Blainville (1818) stimulated intensive research on fishes during the 19th century (e.g., Agassiz, 1833-1843; Münster, 1834, 1839a, 1839b, 1842; Wagner, 1861, 1863; Vetter, 1881; Woodward, 1895) that slowed down in the first half of the 20th century to be invigorated in the second half of the 20th century, especially concerning the study of Jurassic fossil fishes of the Solnhofen Limestone. For example, Nybelin $(1964,1967,1974)$ and Arratia $(1987 \mathrm{a}, 1987 \mathrm{~b}, 1997,1999,2000)$ proposed fundamental changes to the taxonomy of teleosts from the region, and Patterson (1975, 1977), Patterson and Rosen (1977), and Arratia $(1991,1997)$ provided additional morphological infor- 


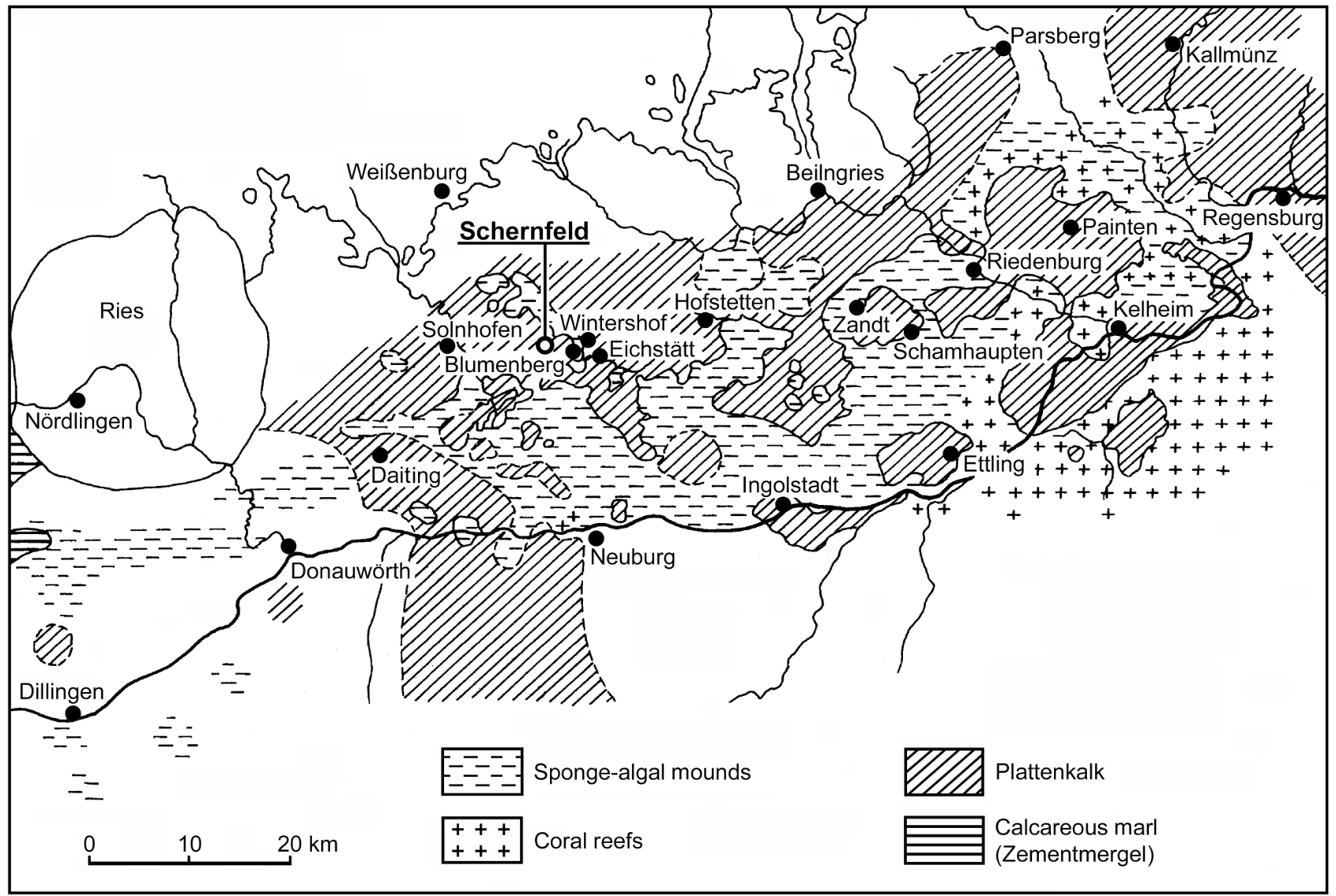

Figure 1. Distribution of plattenkalk basins and reef areas in the southern Franconian Jura during the early Tithonian (modified from Viohl, 1996 with the addition of new localities). The new fish described herein was recovered in the Wegscheid Quarry, near Schernfeld.

mation of some of the teleostean species. Up to 2015, the number of nominal species of teleosts including pachycormiforms and aspidorhynchiforms was 45 (Schultze, 2015). Expectations are that this number will increase because many others remain to be described.

The goals of this contribution are to describe a new species of Tharsis Giebel, 1848 from Wegscheid Quarry near Schernfeld, near Eichstätt, Bavaria, in the Solnhofen limestone (Fig. 1), including a comparison with Tharsis dubius, and to test their phylogenetic position among teleosts. Wegscheid Quarry is the largest quarry within the Eichstätt mining area close to the well-known quarries of Eichstätt-Blumenberg. At present, it is an open pit mine with a diameter of up to $750 \mathrm{~m}$. The area was quarried for decades and yielded thousands of fossils, among them hundreds of specimens of Tharsis dubius.

\section{Material and methods}

The new specimens here described are listed under their corresponding descriptive section. Specimens of Tharsis dubius used for comparisons are listed below. For a list of mate- rial used in the phylogenetic analysis; see Arratia (2017: appendix 1). Specimens studied here are deposited in the following institutions: BSPG, Bayerische Staatssammlung für Paläontologie und Historische Geologie, Munich, Germany; CM, Carnegie Museum, Section of Vertebrate Paleontology, Pittsburgh, Pennsylvania, USA; FMNH, Field Museum of Natural History, Chicago, Illinois, USA; JME, Jura-Museum Eichstätt, Bavaria, Germany; KUVP, University of Kansas, Natural History Museum, Vertebrate Paleontology collections, Lawrence, Kansas, USA; and NHM, Natural History Museum, London, England.

$\dagger$ Tharsis dubius (Blainville, 1818): BSPG 1960 I 194, BSPG 1964 XX 280, BSPG 1961 I 403, BSPG XX III 396, BSPG XX III 444, BSPG XX III 512 and others; CM 4845; FMNH 473, FMNH 25076 and FMNH 25124; JME-2390 (cited as Eichstätt II in Nybelin 1974; only head and few anterior vertebrae preserved), JME-SOS 2401 (cited as Eichstätt I in Nybelin, 1974; only head and part of the vertebral column preserved), JME-SOS 02633 and many specimens from different localities; KUVP 96120, KUVP 96121, KUVP 96123 and KUVP 97043 including histological cross sections of caudal vertebrae; NHM P. 919 (acid-prepared 
specimen), NHM P. 927 (acid-prepared) and NHM P. 51759 (acid-prepared).

The excellent mechanical preparation of the two specimens used in the description of the new species was performed by Dr. Uwe Eller (Dümpelfeld, Germany). Specimens of Tharsis dubius studied herein were mechanically prepared, except for the specimens of the NHM that were acid prepared.

Wild FM 8 and Leica MZ9 stereomicroscopes equipped with a camera lucida were used by the senior author to prepare the line drawings of the specimens. This was carried out under normal light, and we mention this in particular because there are certain differences in the information provided by the documentation of the same structure under normal or UV illumination sources. The specimens were photographed under normal and UV light by $\mathrm{H}$. Tischlinger following the methods described by Tischlinger (2015) and Tischlinger and Arratia (2013). The JME keeps the copyrights of all photographs based on specimens housed in the museum. Illustrations are based directly on specimens rather than photographs. Photographs are not retouched with Photoshop. The latter was only used to label figures.

\subsection{Phylogenetic methodology}

The phylogenetic analysis was conducted using PAUP (Phylogenetic Analysis Using Parsimony) software (version 4.0b10) for 32-bit Microsoft (Swofford, 2000). The phylogenetic analysis used the last list of characters and coding of Arratia (2017, which is an expanded version of Arratia, 2013) with the addition of three new characters (Ch. 196 to 198; Supplement S1) and one new taxon (Supplement S2). The character matrix was constructed using MacClade. All characters are unweighted, unordered, and considered to be independent of one another. The out-groups used in the analysis are fossils and extant neopterygians, e.g., the basal parasemionotiform Watsonulus, the amiiforms Amia calva and A. pattersoni, and the lepisosteiforms Obaichthys and Lepisosteus.

\subsection{Anatomical terminology}

The terminology of the skull roof bones follows Westoll (1943), Jollie (1962) and Schultze (2008). To avoid confusion, all figures show in square brackets the names of bones in the traditional terminology, e.g., parietal bone (frontal): pa (fr). The terminology of the vertebral column follows Arratia et al. (2001) and Arratia (2015), whereas that of the caudal endoskeletal elements (e.g., preural centrum, ural centrum and parhypural) and caudal skeletal types (e.g., polyural or diural) follows Nybelin (1963), Schultze and Arratia (1988, 1989, 2013), and Arratia and Schultze (1992). "True" uroneurals are modified ural neural arches; "uroneural-like" elements are modified preural neural arches; these terms are included in the phylogenetic analysis, and their usage follows Patterson (1973), Arratia and Lambers (1996), and Arratia and Schultze (2013). The terms fin rays, scutes, fulcra, procurrent rays, epaxial rudimentary rays and principal rays follow definitions provided by Arratia $(2008,2009)$. The terminology of scales follows Schultze $(1966,1996)$.

\section{Systematic paleontology}

Class Actinopterygii Cope, 1887

Infraclass Teleostei Müller, 1845 (sensu Arratia, 1999)

Order Ascalaboidiformes, new order

Diagnosis: Same as that of the family Ascalaboidae Arratia, 2016 (see below)

Family Ascalaboidae Arratia, 2016

Genus Ascalabos Graf zu Münster, 1839; Ebertichthys Arratia, 2016; and Tharsis Giebel, 1848.

Tharsis Giebel, 1848

\section{Diagnosis}

(Emended from Nybelin, 1974; based on a unique combination of characters; uniquely derived features among primitive teleosts are identified with an asterisk (*).) Moderately large basal teleosts of about $27 \mathrm{~cm}$ in maximum length and fusiform body with a characteristic bend of the dorsal margin of the caudal fin giving the most posterior part of the body a peculiar shape and slightly asymmetric lobes of the fin $\left(^{*}\right)$; parasphenoid without teeth; middle pit-line groove not extending on pterotic; cephalic sensory canals with numerous and simple sensory tubules; infraorbital 4 deeper than broad in contrast to infraorbital 3; postarticular process of the lower jaw poorly developed; posteroventral margin of preopercle without a notch; vertebrae with heavily ossified autocentra that strongly constrict the notochord; autocentra sculptured with pits, fossae and crests; caudal skeleton with eight or nine hypurals; last caudal vertebrae with a strong inclination of the neural $\left(^{*}\right)$ and haemal $\left(^{*}\right)$ spines toward body axis giving the vertebral column a characteristic aspect; with seven uroneurals distributed in an anterior series of four long uroneurals and other short three uroneurals positioned dorso-posteriorly; two elongate and well-developed tendon-bones "urodermals"; epaxial basal fulcra present; one elongate epaxial fringing fulcrum present.

Content: Tharsis dubius (Blainville, 1818) and T. elleri n. sp. See below Sect. 5 for the content of the genus.

Tharsis elleri n. sp.

Figs. 2-11 


\section{Diagnosis}

Moderately large basal teleost of about $200 \mathrm{~mm}$ in maximum length that differs from Tharsis dubius in the following characters: head comparatively longer, more than $20 \%$ of standard length versus $20 \%$ in Tharsis dubius. Well-developed autosphenotic versus a comparatively smaller bone in $T$. dubius. Complete sclerotic ring formed by two bones oriented anteriorly and posteriorly to the eye versus an incomplete ring formed by two separated anterior and posterior sclerotic bones in T. dubius. Moderately short lower jaw with quadrate-mandibular articulation below the anterior half of the orbit versus comparatively longer lower jaw with quadrate-mandibular articulation below the posterior half of the orbit in T. dubius. With 42 or 43 vertebrae versus 47 or 49 in T. dubius. Caudal vertebrae with neural and haemal arches fused to their respective vertebral centra versus neural and haemal arches autogenous in $T$. dubius. Parapophyses fused to their respective centrum versus autogenous parapophyses in $T$. dubius. Rudimentary epaxial ray present versus no rudimentary ray in $T$. dubius.

\section{Derivation of name}

The specific name elleri honors Dr. Uwe Eller for his devotion and excellence in preparation of fossils, especially those of the Solnhofen limestone.

\section{Holotype}

JME-SOS 08326 is a complete, beautifully preserved specimen of about $190 \mathrm{~mm}$ in total length and ca. $163 \mathrm{~mm}$ in standard length including soft anatomy preservation (part of digestive system) and squamation (Fig. 2a, b).

\section{Paratype}

JME-SOS 08367 is an incomplete specimen, beautifully preserved, lacking pelvic, dorsal and anal fins (Fig. 2c, d).

\section{Type locality and age}

Northeastern section of the large Wegscheid Quarry in the community of Schernfeld, near Eichstätt, Bavaria, Germany. Solnhofen lithographic limestone; lower Tithonian, Altmühltal Formation, Hybonotum zone, Riedense subzone, eigeltingense horizon (Niebuhr and Pürner, 2014; Schweigert, 2015).

\section{Description}

A general description is as follows. The fish is ca. $200 \mathrm{~mm}$ in total length, slightly fusiform (Fig. 2) and with the dorsal fin insertion placed slightly posterior to the midpoint of standard length (55\%). Pelvic fin insertion is at about the midpoint of standard length, slightly in front of the dorsal fin insertion. The caudal peduncle is deep, moderately narrow and about
$88 \%$ of the standard length and $40 \%$ of the body depth The head is proportionally large, about $23 \%$ of the standard length in the beautifully preserved holotype. It has a triangular shape with its three sides having similar lengths, giving the fish a smooth profile. The orbit is moderately large, about $20 \%$ of the head length, and the preorbital region is short, ca. $23 \%$ of the head length. The pectoral fins have a low position, closer to the ventral margin of the body than to the middle region of the flank. The caudal fin presents a characteristic gentle curvature at its dorsal margin so that both lobes of the caudal fin are not symmetric. All exposed surfaces of bones are smooth, without ornamentation and lacking ganoine. The body is covered by large cycloid scales, lacking ornamentation on the free field.

Skull roof and braincase characteristics are as follows. The skull roof is incompletely preserved and/or partially damaged in the holotype and paratype. All bones of the skull roof have smooth surfaces and are not ornamented and have no evidence of a ganoine layer.

According to the contour of the preserved skull roof bones, the dorsal part of the cranium is narrower anteriorly and slightly expanded posteriorly, as is the pattern shown by Tharsis dubius. The main element of the skull roof (Figs. 3, 4) is the parietal bone (frontal) that occupies most of the preorbital region and part of the postorbital region, which is short. Anteriorly, the parietals (frontals) suture with a broad and short mesethmoid (Figs. 3, 4) that bears two short, narrow lateral processes. The parietals (frontals) are damaged so that the interparietal and postparietal sutures are not discernable. A nasal bone is laterally placed to the anterior part of the parietal (frontal), with its posterior part lying on the parietal in the paratype. The bone is narrow and elongate, mainly carrying the anterior section of the supraorbital canal. Due to poor preservation, the limits among the parietal (frontal), postparietal (parietal) and pterotic are not discernable, except for the autosphenotic, which sutures with the pterotic and partially with the parietal (frontal). The autosphenotic is a large bone forming the dorso-posterior corner of the orbit. It is projected ventrolaterally by a well-ossified process. The pterotic is short and together with the autosphenotic are the main elements that articulate with the hyomandibula. The medial and posterior articulations of the pterotic are unclear because of poor preservation. A deep post-temporal fossa (Fig. 3b) is observed at the posterolateral surface of the cranium, but its limits with different cranial bones cannot be established, except that of the pterotic. The middle pit-line groove does not extend onto the pterotic. The posterior region of the pterotic is covered by a broad, triangular-shaped extrascapula (Figs. 3, 4). The supraoccipital (Fig. 3b) is small, with a very low crest. The supraorbital canal, as well as the otic canal, were not observed in the studied material due to incomplete preservation.

The orbitosphenoid is very small so that both eyes are separated by an incomplete interorbital septum. The lateral ethmoid is well developed, but its poor preservation does not 

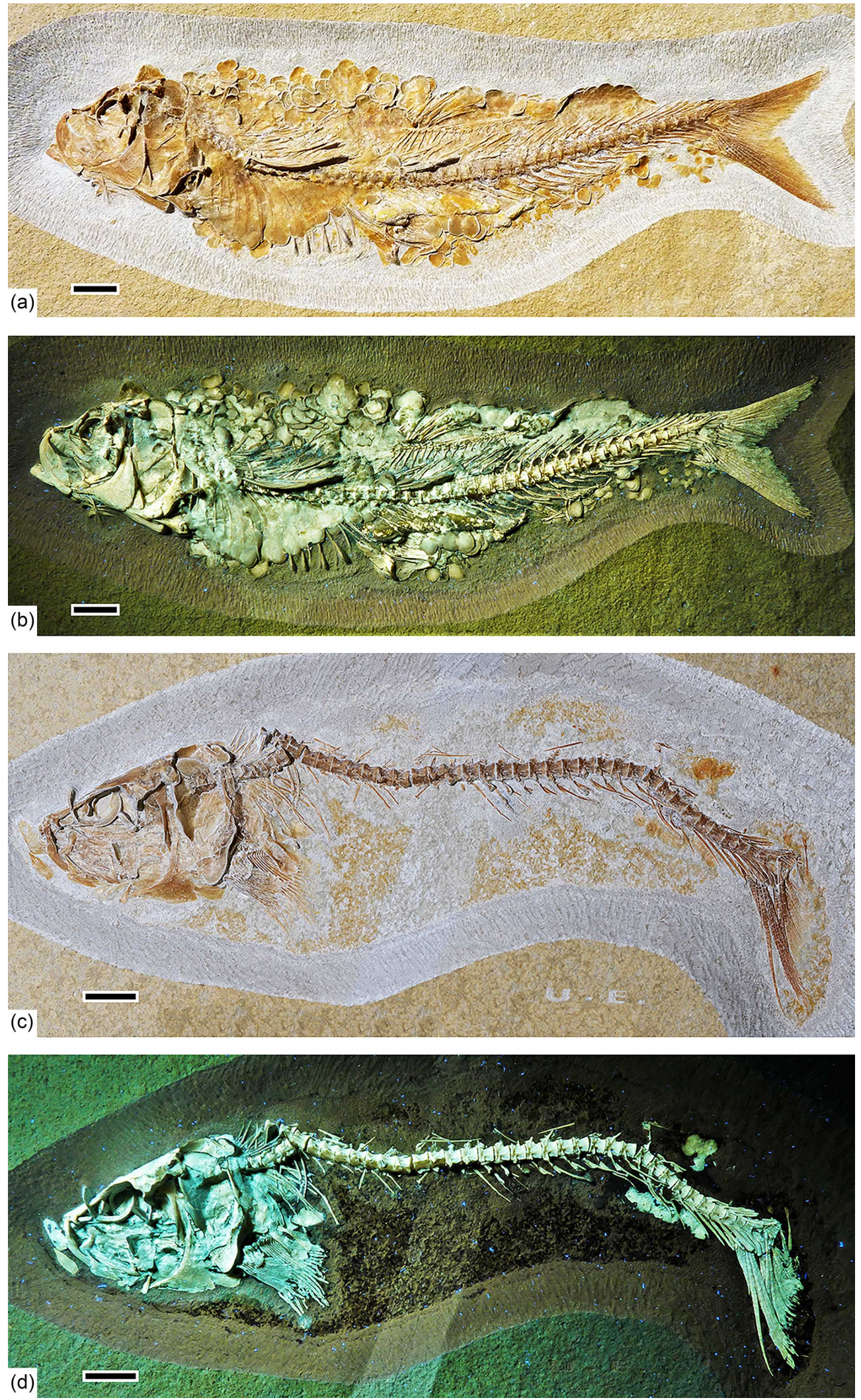

Figure 2. Tharsis elleri n. sp. in lateral view. (a) Holotype JME-SOS 08326 under normal light. (b) Holotype JM-SOS 08326 under UV light. (c) Paratype JME-SOS 08367 under normal light. (d) Paratype JME-SOS 08367 under UV light. Scale bars equal $1 \mathrm{~cm}$. 

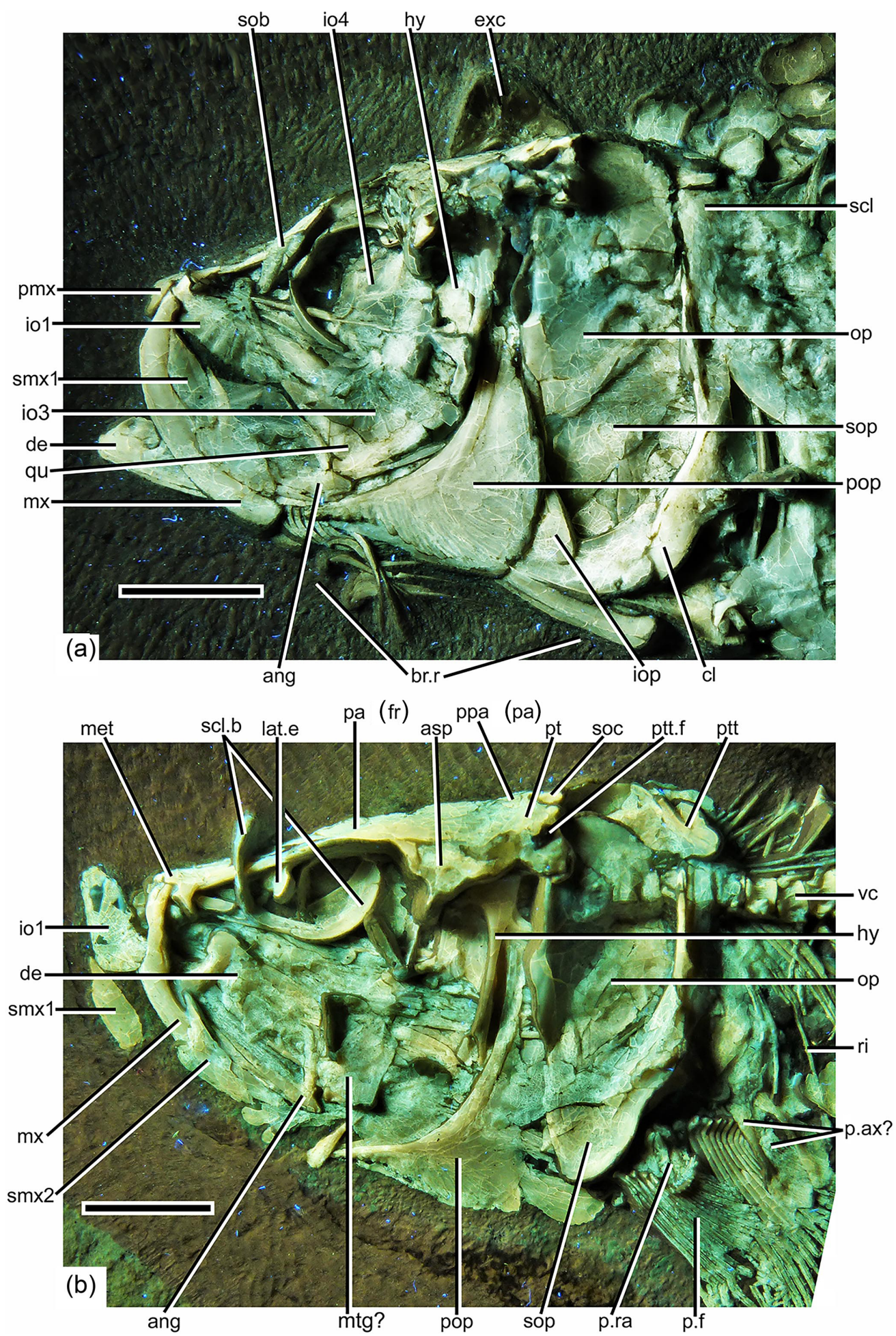

Figure 3. Photographs of the head of Tharsis elleri n. sp. under UV light. (a) Holotype (JME-SOS 08326). (b) Paratype (JME-SOS 08367). Scale bars equal $1 \mathrm{~cm}$. Abbreviations are as follows: ang, angular; asp, autosphenotic; br.r, branchiostegal ray; cl, cleithrum; cor, coracoid; de, dentary; exc, extrascapula; hy, hyomandibula; io1-4, infraorbitals 1-4; iop, interopercle; lat.e, lateral ethmoid; met, mesethmoid; mtg?, metapterygoid; mx, maxilla; op, opercle; pa (fr), parietal bone (frontal); par, parasphenoid; p.f, pectoral fin; p. ax?, pectoral axillary process?; pop, preopercle; ppa (pa), postparietal bone (parietal); pmx, premaxilla; p.ra, pectoral radial; pt, pterotic; ptt, posttemporal; ptt.f, posttemporal fossa; qu, quadrate; ri, rib; scl, supracleithrum; scl.b, sclerotic bones; smx1-2, supramaxillae 1-2; sob, supraorbital bone; soc, supraoccipital; sop, subopercle; sy, symplectic, vc, vertebral centrum. 


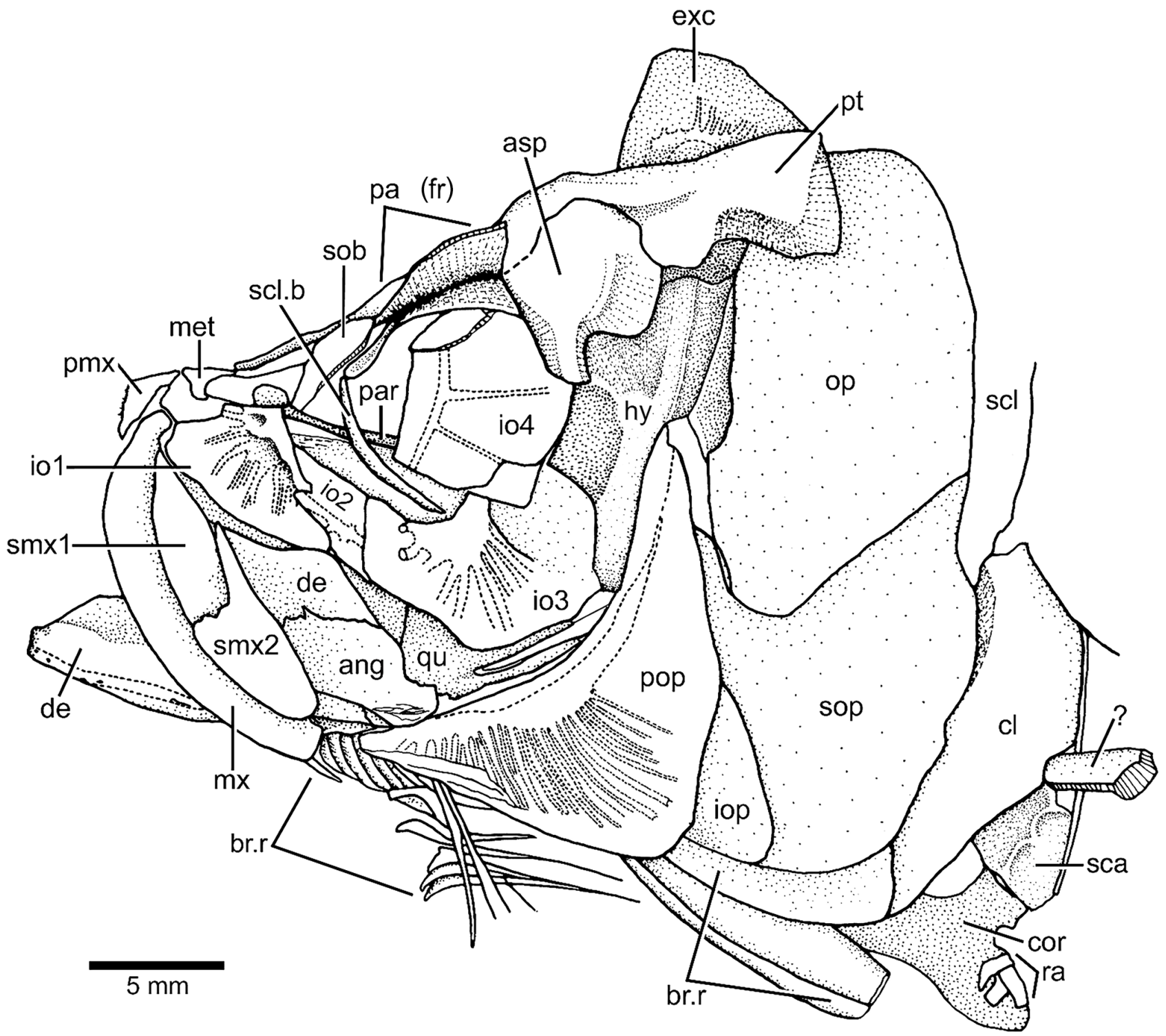

Figure 4. Tharsis elleri n. sp. Drawing of head bones in lateral view (JME-SOS 08326) based on specimen under normal light. Abbreviations are as follows: ang, angular; asp, autosphenotic; br.r, branchiostegal ray; cl, cleithrum; cor, coracoid; de, dentary; exc, extrascapula; iop, interopercle; , hy hyomandibula; io1-4, infraorbitals 1-4; met, mesethmoid; mx, maxilla; op, opercle; pa (fr), parietal (frontal); par, parasphenoid; pmx, premaxilla; pop, preopercle; pt, pterotic; qu, quadrate; ra, pectoral radial; scl, supracleithrum; scl.b, sclerotic bone; smx1-2, supramaxillae 1-2; sob, supraorbital; sop, subopercle; ?, unidentified bone.

allow a proper description. A section of the parasphenoid is visible throughout the orbit. There are no teeth associated with the ventral surface of the bone or scattered below the parasphenoid.

Orbit and circumorbital series are as follows. The fish has a moderately large orbit (Figs. 3, 4) so that the space between the posterior margin of the orbit and the anterior margin of the preopercle is narrow. The series of circumorbital bones apparently encloses the orbit completely, although an antorbital and dermosphenotic are not preserved. The series has preserved a supraorbital and four infraorbitals (Figs. 3, 4).
There are two large markedly concave sclerotic bones occupying anterior and posterior positions and are sutured to each other (Figs. 3b, 5).

The supraorbital (Figs. 3, 4) is an elongate, well-ossified bone that narrows antero-ventrad. It is partially displaced and incompletely preserved in the holotype. An antorbital is not preserved.

Infraorbital 1 (lacrimal) (Figs. 3, 4) is a triangular-shaped bone that is heavily ossified close to the orbital margin but is thinly ossified antero-ventrally. Infraorbital 2 (Figs. 3, 4) is partially displaced below infraorbitals 1 and 3 so that its 


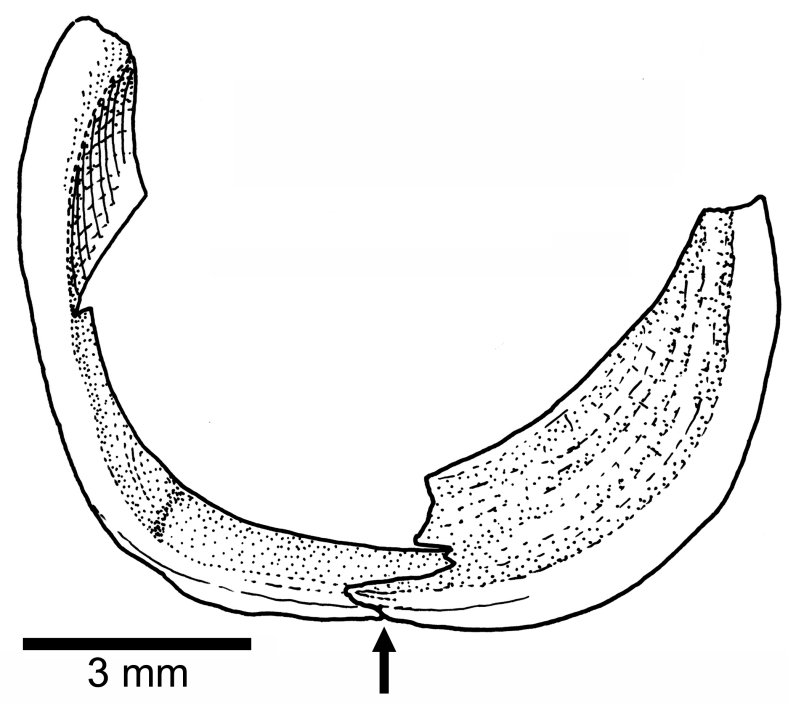

Figure 5. Tharsis elleri n. sp. Drawing of the partially preserved sclerotic bones in the paratype JME-SOS 08367. An arrow points to the ventral contact between anterior and posterior sclerotic bones.

complete length is unknown, but the preserved section reveals that the bone was broader than that in Tharsis dubius. Infraorbital 3 (Figs. 3, 4) is a large, broad bone at the posteroventral corner of the orbit. It narrows anteriad so that part of the ectopterygoid and quadrate are exposed laterally; dorsally, infraorbital 3 has a region without sensory tubules that gives the impression that it is an articulatory surface for infraorbital 4. Its posterior margin does not reach the anterior margin of the preopercle, and both bones are separated by a short distance. Infraorbital 4 is displaced and it would form most of the posterodorsal margin of the orbit in life. Its antero-dorsal corner is broken in the holotype. It is a large, broad, slightly square bone. Infraorbital 5 is not preserved, but considering the space left at the posterodorsal region of the orbit, it is assumed that it was the smallest bone of the series.

The infraorbital canal (Fig. 4) is enclosed by bone and is of simple type. The main canal is relatively broad in infraorbitals 1 and 3 and narrower in infraorbitals 2 and 4. About eight sensory tubules are preserved in infraorbital 1 ; they do not reach the ventral margin of the bone. Infraorbital 2 shows two short tubules, and infraorbital 3 has preserved 10 tubules of different length. Infraorbital 4 has two long tubules.

The upper jaw is as follows. Premaxilla, maxilla and two supramaxillae form the upper jaw. The premaxilla (Figs. 3, 4) is a slightly triangular bone, with a short, narrow ascendant process and a short oral margin, apparently bearing small, conical teeth, as inferred by the presence of a few small tooth sockets.

The maxilla (Figs. 3, 4) is narrow and gently curved and slightly shorter than the lower jaw, not covering the lateral aspect of the quadrate. Its posterior end is below the ante- rior half of the orbit. Its articulatory anterior region is bent and looks short in the holotype; in contrast, it is longer in the paratype. The ventral margin is gently convex, and its posterior margin is truncated in the holotype; it is not preserved in the paratype. An incomplete row of a few minuscule sockets for teeth is present in the oral margin.

Two supramaxillae (Figs. 3, 4) cover most of the dorsal margin of the maxilla in the holotype, whereas they are displaced in the paratype. Supramaxilla 2 has a broad, expanded body and a narrow, long antero-dorsal process that covers half of the dorsal margin of supramaxilla 1 , which is slightly ovoid, with its posterior margin truncated.

The lower jaw is as follows. The jaw (Figs. 3, 4) is relatively short, with the quadrate-mandibular articulation placed below the anterior half of the orbit. The jaw is formed laterally by two bones - the dentary (dentalosplenial of Nybelin, 1974) and angular. The suture between both bones reveals that the dentary forms most of the jaw. From a narrow mandibular symphysis, the dentary expands abruptly dorsoposteriad, producing a massive and high coronoid process that is thicker and strongly ossified at the antero-dorsal region of the coronoid process. The latter has a small contribution of the angular. A very narrow "leptolepid" notch is observed in the paratype under normal light, just in front of the massive anterior margin of the coronoid process. A tiny bone at the posteroventral corner of the angular may be the retroarticular. This region is unclear in the holotype because the angular presents an irregular surface at this corner. The postarticular process is short.

A surangular is not present at the posterodorsal corner of the jaw. Since the jaw is preserved in lateral view in the holotype and paratype, presence or absence of coronoid bones and prearticular bones cannot be verified, but they are absent in Tharsis dubius.

The mandibular canal is positioned near the ventral margin of the jaw, and it opens to the surface by a few small pores lying on the bony canal. Pores have not been observed in the posteroventral region of the angular, so it is assumed that the mandibular canal exits here medially.

Most of the palatoquadrate, suspensorium, hyoid arch and urohyal are partially hidden below other bones so that the description is restricted to a few elements.

A small section of the ectopterygoid (Figs. 3, 4) is visible in front of the quadrate. The quadrate (Figs. 3,4) is slightly triangular and has a comparatively small, slightly rounded condyle for the articulation with the lower jaw and an elongate posterodorsal process inclined slightly ventrally. The complete length of the posterodorsal process of the quadrate and of the symplectic is unknown because the bones are covered by the anterior margin of the preopercle. A displaced bone, which is interpreted here as a possible metapterygoid (Figs. 3, 4) is observed in the paratype. The hyomandibula (Figs. 3, 4) is a narrow, long bone slightly inclined anteroventrad. Its dorsal region articulating with the cranium is well ossified and continues ventrally as a well-ossified narrow 
shaft that presents an anterior membranous flange up to its mid-length. The dorsal portion of the hyomandibula is narrow and apparently has only one elongate articular condyle with the braincase. The opercular process is well ossified and closer to the cranial articulatory surface of the bone than to its middle region. The main shaft of the bone has no expansion or process at its ventro-posterior margin. Considering the length of the jaw and the position of the quadratemandibular articulation, the symplectic is assumed to be a long bone that is partially exposed in the holotype; an alternative possibility is the presence of an elongate cartilaginous articulatory region filling the space between the ventral margin of the hyomandibula and the dorso-posterior margin of the symplectic.

The lower part of the hyoid arch preserves a small section of the anterior ceratohyal in the holotype that is uninformative. The urohyal is not preserved.

The opercular and branchiostegal series are as follows. The preopercle (Figs. 3,4) is a large and triangular-shaped bone, which is expanded posteroventrad. It lacks a slightly rounded flange just anterior to the curvature of the preopercular canal and a notch at the posterior margin of the bone is not present. Its dorsal arm is longer than the ventral one, almost reaching the posterolateral margin of the pterotic. The preopercular canal (Fig. 4) gives off many tubules, filling the ventral arm and part of the dorsal arm. The tubules are very delicate, simple and narrow, one next to the other, and open irregularly near the posteroventral margins of the bone in the holotype. A few long tubules bear - at mid-length - a very short branch ending in a small pore in the paratype.

The opercle (Figs. 3, 4) is broken in the holotype and paratype, but still it is possible to see it as a large bone with its dorsal margin gently rounded, whereas its anterior and posterior margins are almost straight, and the ventral margin is markedly oblique. The surface of the bone is smooth, with its anterior margin thickened and heavily ossified in the paratype. The subopercle (Figs. 3, 4) is large, as broad as the opercle and slightly smaller. Although its ventral margin is broken, it is possible to observe that it is gently curved, with a well-developed antero-dorsal process. The partially displaced interopercle (Figs. 3, 4) is covered by the posterior margin of the preopercle so that its complete shape and size are unknown.

There are nine short branchiostegal rays associated with the anterior ceratohyal, plus seven other displaced rays lying below the articulated branchiostegal rays and three other broad, large posterior elements just below the interopercle and subopercle that likely articulate with the posterior ceratohyal (Figs. 3, 4). Therefore, about 20 rays can be counted in the holotype. However, and by comparison with Tharsis dubius, it could be possible that the number was higher. A gular plate has not been observed.

Vertebral column, intermuscular bones and ribs are as follows. There are 42 or 43 vertebrae, including preural centrum 1; from these, 24 or 25 are abdominals or precaudals so that the caudal region is shorter than the abdominal one. The first four or five vertebrae are covered laterally by the opercle. All vertebrae are heavily ossified, and their lateral surfaces (Figs. 2, 5) are covered by a series of small pits and grooves that give the vertebrae a smoother surface than that found in Tharsis dubius. The centra are slightly deeper than long in the abdominal-precaudal region, whereas they are squareshaped anteriorly and posteriorly (Fig. 2c, d). The preural centra are slightly deeper than long, and the ural centra are reduced in size. All centra lack pre- and postzygapophyses.

The neural arches of the abdominal vertebrae (Figs. 2, 6, 7) are autogenous, and the halves of each arch are unfused medially. Each epineural process emerges at the posterolateral margin of the arch. The neural spines are shorter than the epineural processes, and they are slightly inclined posteriorly toward the horizontal below the dorsal pterygiophores. The short parapophyses (Fig. 6b) are fused to the antero-lateral portion of the centrum, near its ventral margin. The head of each rib articulates with a small articular cavity present in each parapophysis.

The neural arches of the caudal vertebrae (Figs. 2, 6a, b) are fused to their centra, except in the first two that are unfused or show incomplete lines of suture in the holotype; they have characteristic elongated processes at the dorsal margin of the arch. They are long and directed anteriorly in the preural region, whereas they are characteristically curved in precaudal vertebrae (Fig. 6a). All haemal arches are fused to their respective centrum. The neural and haemal spines of the caudal region are narrow, with the exception of those of the preural centra. The neural and haemal spines are moderately inclined toward the body axis in the precaudal region, increasing their inclination caudally. The haemal spines (Fig. 6a) are short, not extending between the anal pterygiophores, except for the first two. The neural and haemal spines of the mid-caudal region are ossified, lacking an internal core of cartilage; however, the condition changes in the preural region (see below).

There is an unclear condition of the haemal arch and spine in the first caudal centra (Fig. 6), with a complete haemal arch closed ventrally and a haemal spine that is not a ventral continuation of the arch but appears to be separated. This condition is lost in more posterior vertebrae showing a "normal" arch and spine.

The total number of ribs cannot be counted precisely because scales cover them in the holotype, whereas they are not preserved in the paratype. The ribs are well ossified and reach close to the ventral margin of the body. The ribs are narrow along their length but slightly expanded at their proximal small articulatory heads. The last pair is positioned anterior to the first anal pterygiophore.

Supraneural bones are not preserved or are covered by other structures. The epineural processes of the neural arches (Figs. 2, 6a) extend along the abdominal region, ending close to the last dorsal pterygiophore. The epineural processes are long, extending laterally along the space occupied by several 

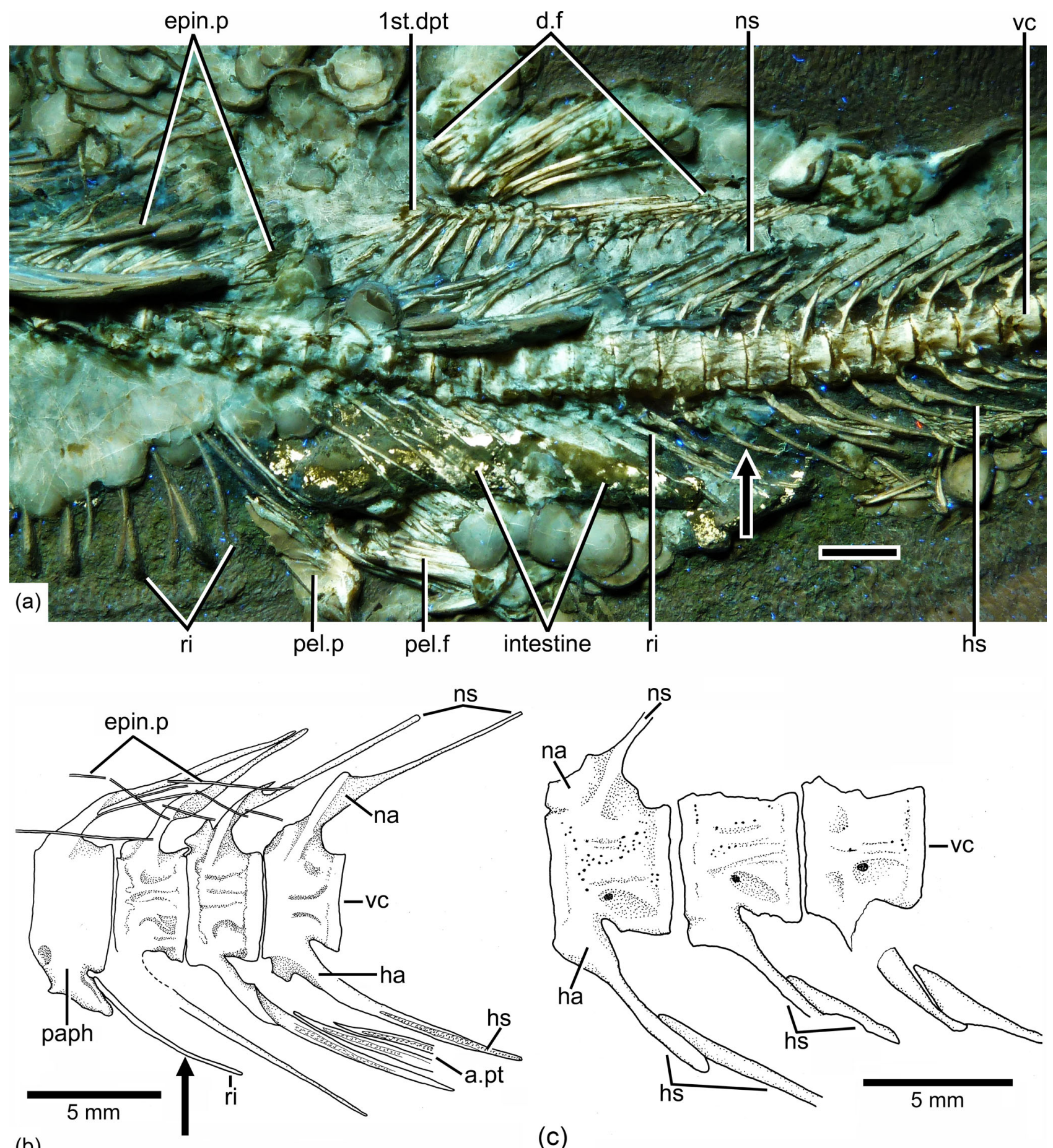

(b)

(c)

Figure 6. Tharsis elleri n. sp. Details of the middle body region and of certain vertebrae. (a) Limit between abdominal and caudal regions in the holotype JME-SOS 08326 under UV light, dorsal and pelvic fins, and intestine. Scale bar is $5 \mathrm{~mm}$. (b) Line drawing of vertebral region illustrated in (a). The arrows in (a) and (b) mark the same rib. (c) Line drawing of similar vertebral region in the paratype (JME-SOS 08367). Abbreviations are as follows: 1st.dpt, first dorsal pterygiophore; a.pt, remains of anal pterygiophore; d.f, dorsal fin; epin.p, epineural process; ha, haemal arch; hs, haemal spine; na, neural arch; ns, neural spine; paph, parapophyses; pel.f, pelvic fin; pel.p, pelvic plate; ri, rib; vc, vertebral centra. 


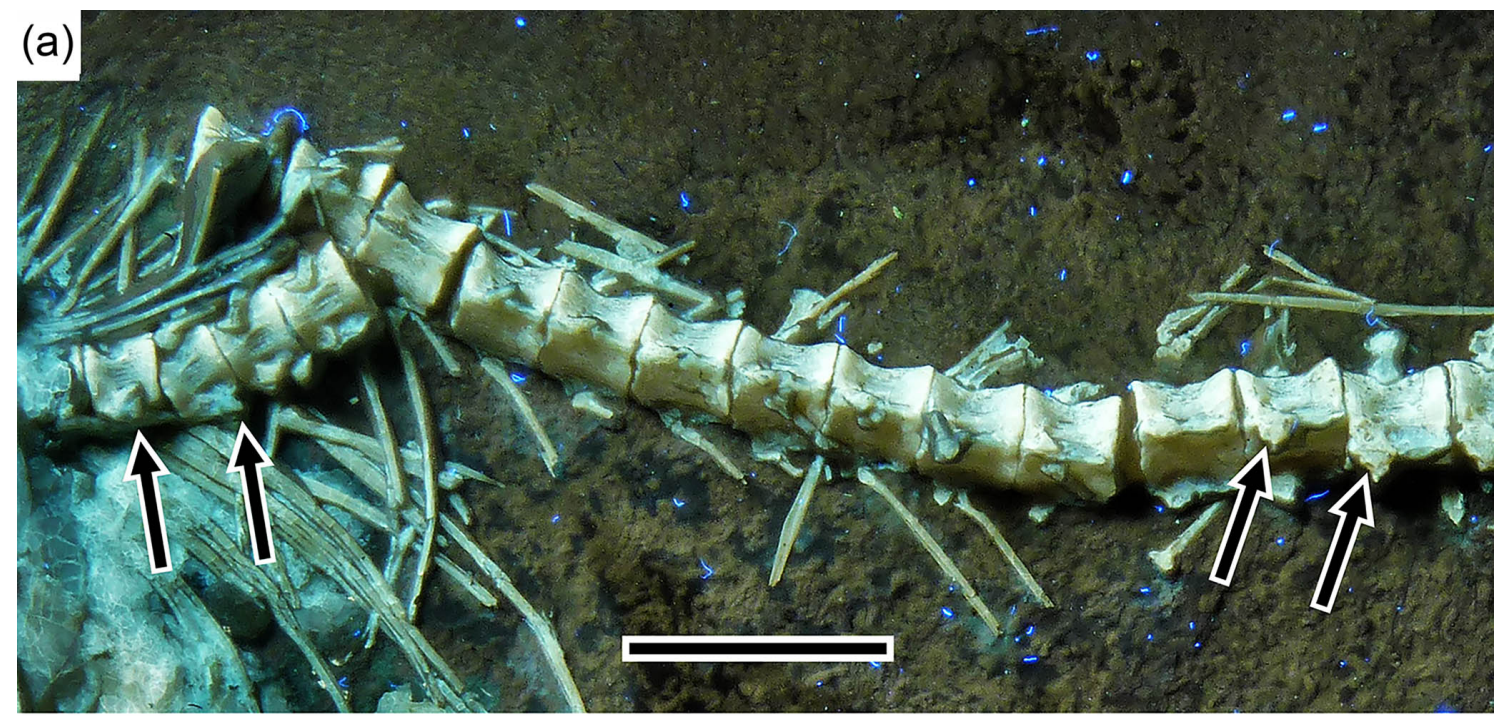

(b)

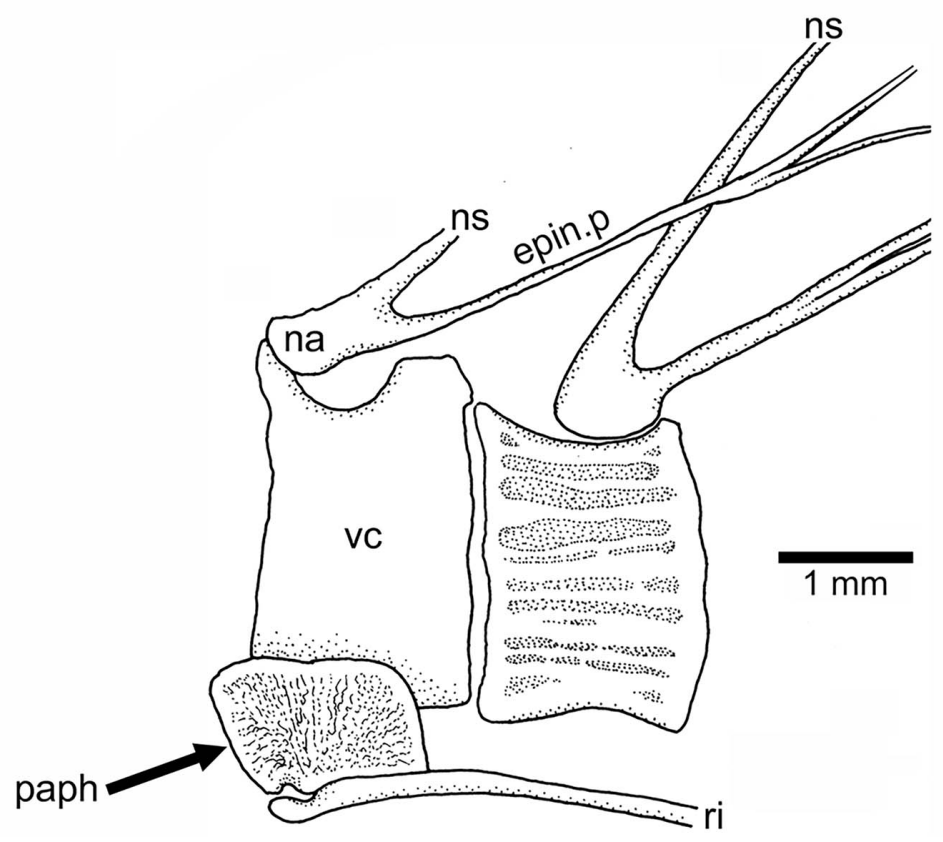

Figure 7. Tharsis elleri n. sp. (a) Section of the abdominal region of the vertebral column of the paratype JME-SOS 08367 illustrating the parapophyses (arrows) fused to their respective centrum. Scale bar equals $5 \mathrm{~mm}$. (b) Abdominal vertebrae of Tharsis dubius (JME-SOS 02633) illustrating the autogenous condition of the parapophysis. Abbreviations are as follows: epin.p, epineural process; na, neural arch; ns, neural spine; paph, parapophysis; ri, rib; vc, vertebral centrum.

centra. They are thin, but heavily ossified, and curved posterodorsally, with the exception of the last ones, which lie closer to the dorsal margin of the centra than to the tips of the neural spines. Only a few fragments of epipleural bones are preserved.

Pectoral girdles and fins are as follows. The bones of the pectoral girdle and fins are poorly preserved. The posttemporal is observed in medial view in the paratype (Figs. 2c, d, $3 b)$. It is a relatively small bone, with a rounded, posterior end, broadening anteriorly and with a well-ossified dorsal process for articulating with the cranium. The ventral arm is not observed due to the position of preserved bone. The main lateral line is not observed.

The supracleithrum (Figs. 3b, 4) is incompletely preserved in the holotype, but it seems to be an elongate bone. It is broad at its dorsal tip, but narrowing ventrally; however, its mid-region is damaged. The trajectory of the lateral line is not observed. The cleithrum (Figs. 3, 4) is a heavily ossified bone with a long dorsal limb that only has its anterior margin preserved. The cleithrum is slightly expanded at its pos- 
teroventral corner and becomes narrower at its short, ventral limb. The number of postcleithra and their characters cannot be described due to poor preservation.

The scapula and coracoid (Fig. 4) are preserved in the holotype, but they are not informative. Four elongate proximal radials are observed in the paratype (Fig. 3b), with the first and last ones being shorter than the second and third proximal radials.

The pectoral fin (Fig. 3b) is positioned near the ventral margin of the body. The total number of pectoral rays is unknown, but 10 rays are preserved in the right fin, whereas ca. 14 rays are preserved in the left fin in the paratype. All rays have very long bases and are scarcely branched (one branching in most of them) and scarcely segmented distally. In addition, there are two structures in the paratype that may be pectoral axillary processes lying on one of the pectoral fins (Fig. 3b).

Pelvic girdles and fins are as follows. The pelvic girdles (Fig. 6a) are poorly preserved in the holotype and are missing in the paratype. A large well-ossified, triangular basipterygium (pelvic plate) is preserved in the holotype. The posterior part of the basipterygium is thick and retains a large core of cartilage, but it is incomplete so that it is not possible to determine the presence of a posterior process or not. Both pelvic fins are displaced and together so that the number of rays per fin cannot be determined. The pelvic rays have long bases, but not as long as the pectoral rays.

Dorsal and anal fins are as follows. The dorsal fin (Figs. 2a, b, 6a) is incompletely preserved with its rays partially displaced so that a total number of dorsal fin rays cannot be provided, but considering that the holotype has about 15 dorsal pterygiophores preserved, this could indicate that the fin has more than 15 rays.

The first dorsal pterygiophore (Figs. 6a, 8a) is a large complex bone that expands antero-ventrally and has several processes that are preceded by a flat bony flange that gives a characteristic shape to the first pterygiophore. Pterygiophores 2-4 are of similar length, whereas most posterior pterygiophores decrease slightly in size and thickness posteriorly. The basal or proximal radial portion of the pterygiophores, except the first one, are triangularly shaped. There is no information available concerning middle radials and distal radials because of conditions of preservation.

Only a few incomplete rays and fragments of the first pterygiophores of the anal fin are preserved.

The caudal fin and endoskeleton are as follows. The caudal fin and endoskeleton are well preserved in the holotype and paratype. The caudal fin (Figs. 2, 9, 10) is deeply forked, with very short middle principal rays compared to the long, leading marginal rays; the lobes are slightly asymmetric due to a slight bend of the dorsal or epaxial lobe.

Five or six preural vertebrae support the caudal rays. The preural vertebrae (Figs. 9, 10) are characterized by their smooth surfaces covered by series of small pits and some small ridges, and their broad dorsal and ventral arcocentra are fused to their respective centrum. The preservation of the neural spines of preural vertebrae 5-2 suggests they have a central core of cartilage surrounded by a thin perichondral ossification. In the vertebrae that are completely preserved, an anterior process at the base of neural spines 4 to 2 is preserved. Neural spines 5 to 2 are elongate but decrease in length posteriorly, whereas the neural spine of preural centrum 1 is shorter (or even may be absent) than the preceding ones. The haemal spines of preural centra 5-1 are broader than their respective neural spines, especially haemal spines $3-1$. However, the haemal spine of preural vertebra 5 is narrower. The haemal spines of the preural vertebrae are heavily ossified chondral elements.

The neural and haemal arches of preural vertebra 1 (Figs. 9, 10) are fused to their centrum. A complete neural arch, with a rudimentary spine, is present on preural centrum 1. The haemal arch and its broad parhypural are fused to the centrum. A well-developed hypurapophysis on the lateral wall of the haemal arch of preural centrum 1 is observed in the holotype and paratype.

Three or four ural centra (of the polyural terminology; or two centra of the diural terminology) are associated with their respective hypurals. An elongate first ural centrum bears hypurals 1 and 2 (Figs. 9, 10), whereas the longer posterior ural centrum is associated with hypurals 3 and 4 . A long arch bearing its spine is present above ural centra 1 and 2 .

The complete number of uroneurals is unclear. The holotype has five preserved uroneurals (Fig. 9) distributed in a series of four elongate ones and one short one placed at a different angle. The paratype also has the anterior series of four long uroneurals and in addition two small uroneurals. The first uroneural is the longest of the series and extends anteriad, reaching the lateral surface of preural centrum 3; it extends even further in the holotype. The second uroneural reaches the lateral surface of preural centrum 3 or 2 , and the third uroneural reaches the lateral surface of preural centrum 1. The fourth uroneural is short, reaching anteriorly the lateral surface of ural centra 1 and 2 or the bases of hypurals 1 and 2 that are fused at their bases. Uroneural 5 is smaller, fusiform shaped and oriented almost parallel to the bases of the dorsal principal rays (in the holotype), but after comparison with Tharsis dubius, it is assumed here that the uroneural is displaced from its position. There are three short, narrow epurals in the holotype, but two are preserved in the paratype.

Seven hypurals (Fig. 10) are preserved in the paratype, and still there is space for two more. Hypurals 1 and 2 are continuous at their bases, and they are not fused to the autocentrum of ural centra 1 and 2. Hypural 1 is the longest element of the series, and hypural 3 is the broadest. However, hypural 3 is not completely preserved in the paratype. The breadth of the hypural diastema is unclear. Hypurals 1 and 2 (Fig. 9) are partially covered by the expanded bases of the middle principal rays (e.g., rays 10 and 11). Principal rays 8 and 9 (Fig. 9) have well-developed dorsal processes at their bases. 
(a)

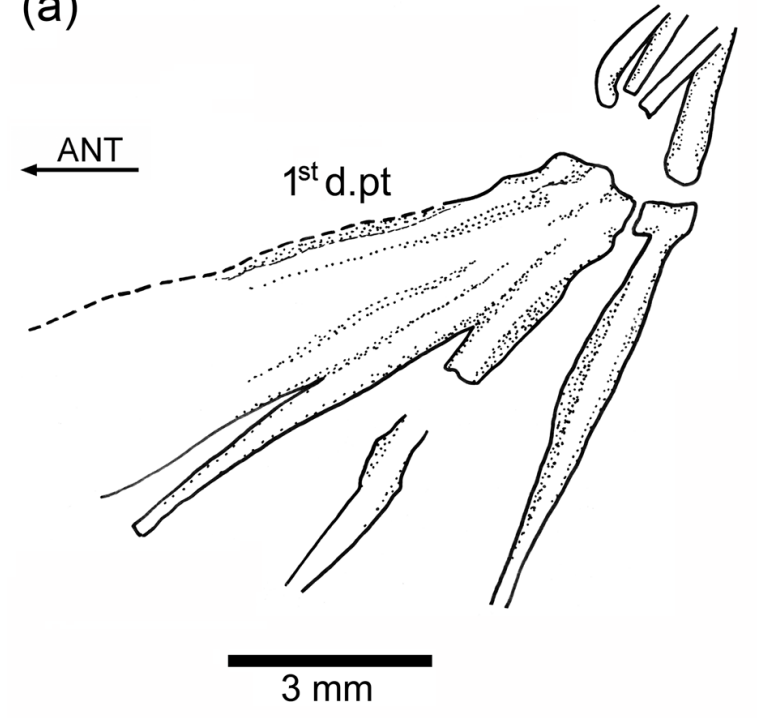

(b)

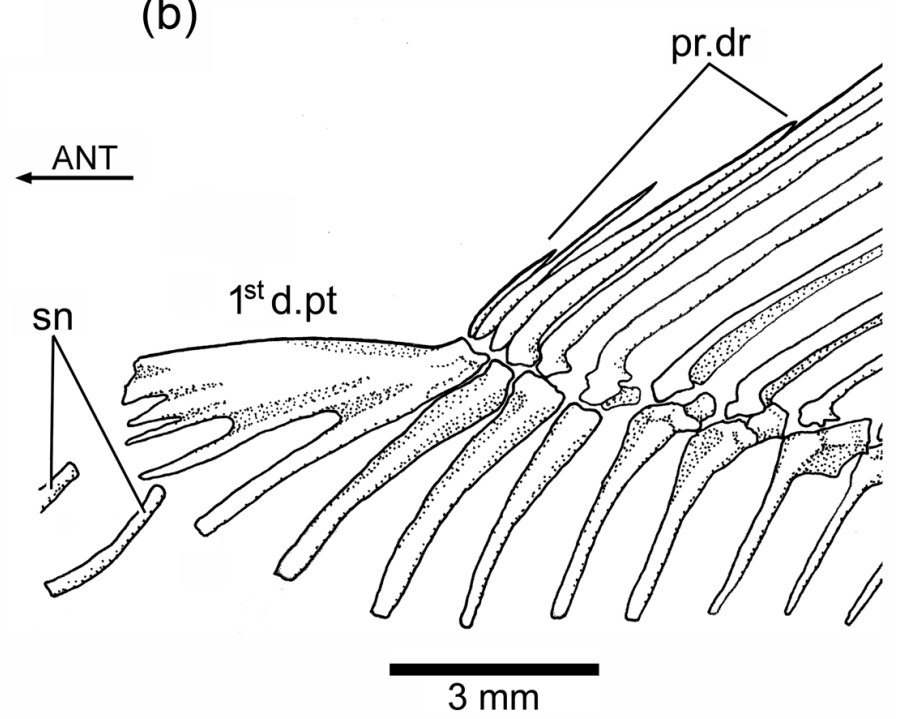

Figure 8. Tharsis elleri n. sp. (a) First dorsal pterygiophore of the holotype JME-SOS 08326. (b) First dorsal pterygiophore and associated bones of Ebertichthys ettlingensis (modified from Arratia, 2016). Abbreviations are as follows: 1std.pt, first dorsal pterygiophore; ANT, anterior direction; pr.dr, dorsal procurrent rays; sn, supraneurals.

The holotype has three epaxial basal fulcra preserved, one rudimentary epaxial ray, one fringing fulcrum, 19 principal rays and at least five hypaxial procurrent-segmented rays; there are four other ray bases that could belong to hypaxial basal fulcra or procurrent rays (Fig. 9). One long and slightly fusiform dorsal scute and a slightly shorter ventral scute precede the epaxial and hypaxial lobes, respectively.

The anterior epaxial basal fulcra (Fig. 9) are elongate, leaflike elements that expand laterally, partially covering the next fulcrum in the holotype. The elongate fringing fulcrum lies between the distal tip of the epaxial rudimentary ray and the dorsal margin of the first principal ray. It is unclear whether a tiny additional fulcrum is present at the distal end of the fringing fulcrum or the fringing fulcrum is damaged distally. The epaxial rudimentary ray (Fig. 9) has a short base and at least two segments (see definition of this kind of ray in Arratia, 2008).

A total of 10 principal caudal fin rays are articulated with hypural 2 plus all dorsal-most hypurals. The bases of the principal rays may reach hypural 2 (Fig. 9) due to the bend of the dorsal lobe of the caudal fin. The articulation among segments of most principal rays is mainly $\mathrm{Z}$ or step like, whereas the articulation among segments of the inner principal rays is mainly straight.

Two well-developed, elongate urodermals (sensu Arratia and Schultze, 1992) lie on the bases of the first and second principal rays in the holotype (Fig. 9).

Scales are as follows. Thin, large cycloid scales of about 3 to $5 \mathrm{~mm}$ in length in the holotype cover the whole body. No radii are observed. Each scale has circuli around a small focus, and the circuli are only missing at the posterior part of the scale (Fig. 11). Poorly preserved remnants of scales are observed on the lateral surface of some caudal fin rays.

The intestine is as follows. A portion of the intestine is preserved on the holotype (Figs. 2a, b, 6a). The filled intestine from stomach (pylorus) to anus is preserved in the holotype. The intestine is straight as in Clupea (Harder, 1975: fig. 130) and does not show loops as in advanced or herbivorous teleosts, nor a spiral valve as in primitive actinopterygians. The filling consists of an amorphous mass with pieces of bones and scales.

\section{Phylogenetic relationship of Tharsis elleri $\mathrm{n}$. sp.}

To assess the phylogenetic relationships of Tharsis dubius and T. elleri n. sp., a cladistic analysis of 43 advanced neopterygian taxa and 198 characters was performed. For the list of characters see Supplement S1 and for the coding of characters see Supplement S2.

A parsimony analysis was performed using PAUP 4.0 beta 10 (Swofford, 2000), using ACCTRAN character-state optimization, a heuristic search using a random addition sequence with 500 replicates, and the tree bisection and reconnection (TBR) branch-swapping algorithm. The parsimony analysis recovered one tree of 549 steps (retention in$\operatorname{dex}=0.7874$; consistency index $=0.4609$; Fig. 12).

Figure 12 represents the only tree found. The topology of this tree differs from that of Arratia (2017) in the addition of Tharsis elleri $\mathrm{n}$. sp. as a sister taxon of Tharsis dubius and in the interpretation of certain characters. For some characters with a few question marks, the parsimony analysis set forward some predictions or assumptions as potential synapo- 

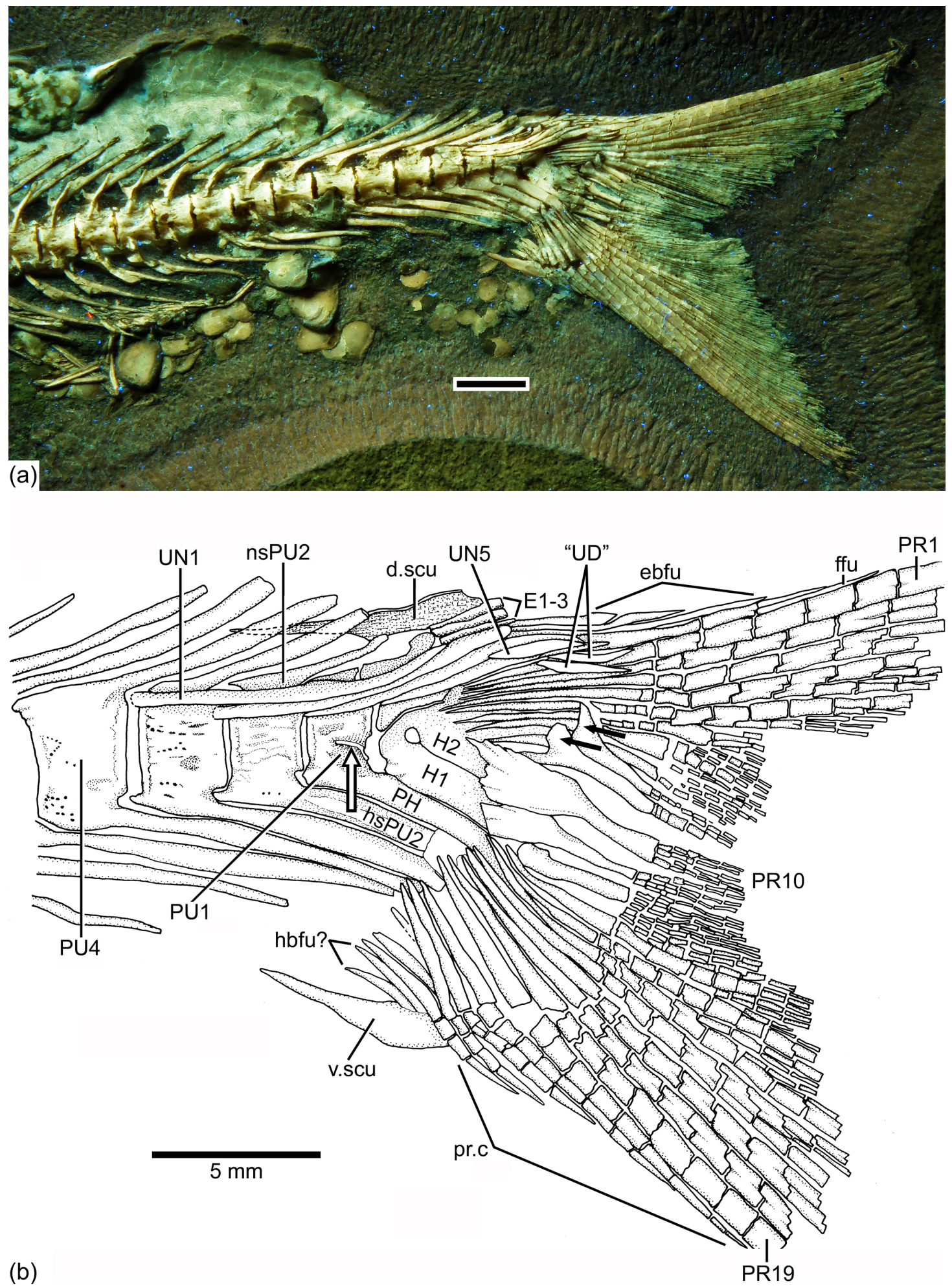

Figure 9. Caudal endoskeleton and tail in lateral view of the holotype JME-SOS 08326. (a) Photograph of the posterior part of the body of the specimen under UV light. (b) Drawing of the caudal skeleton. The white arrow points to the hypurapophysis; the two black arrows point to the dorsal processes of principal caudal fin rays. Abbreviations are as follows: d.scu, dorsal caudal scute; E1-3, epural 1-3; ebfu, epaxial basal fulcra; ffu, fringing fulcrum; H1-2, hypurals 1-2; hbfu?, hypaxial basal fulcra?; hsPU2, haemal spine of preural centrum 4; nsPU, neural spines of preural centrum 2; PH, parhypural; prp, procurrent ray; PU1, 4, preural centra 1, 4; "UD", "urodermal"; UN1-4, uroneurals 1-4; PR1-19, principal rays 1-19; v.csu, ventral caudal scute. 

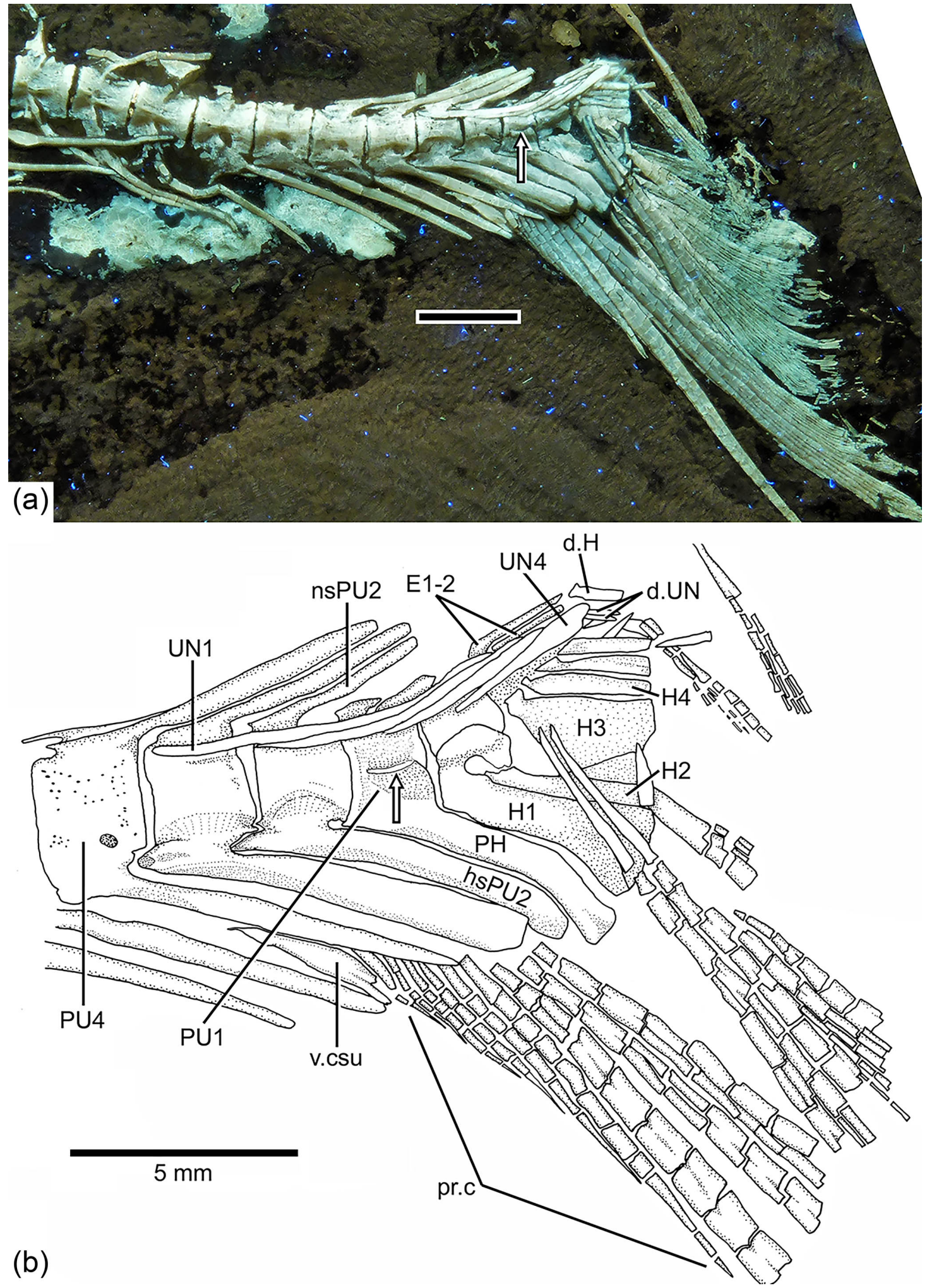

Figure 10. Tharsis elleri n. sp. Caudal endoskeleton and tail in lateral view of the holotype JME-SOS 08326. (a) Photograph of the posterior part of the body of the specimen under UV light. Scale bar equals $5 \mathrm{~mm}$. (b) Drawing of the caudal skeleton. Arrow points to the hypurapophysis. Abbreviations are as follows: d.H, displaced hypural; d.UN, displaced uroneural; H1-4, hypurals 1-4; hsPU2, haemal spine of preural centrum 2; nsPU2, neural spines of preural centrum 2; PH, parhypural; pr.c, procurrent ray; PU1, 4, preural centra 1, 4; UN1-4, uroneurals 1-4; PR1-19, principal rays 1-19; v.csu, ventral caudal scute. 


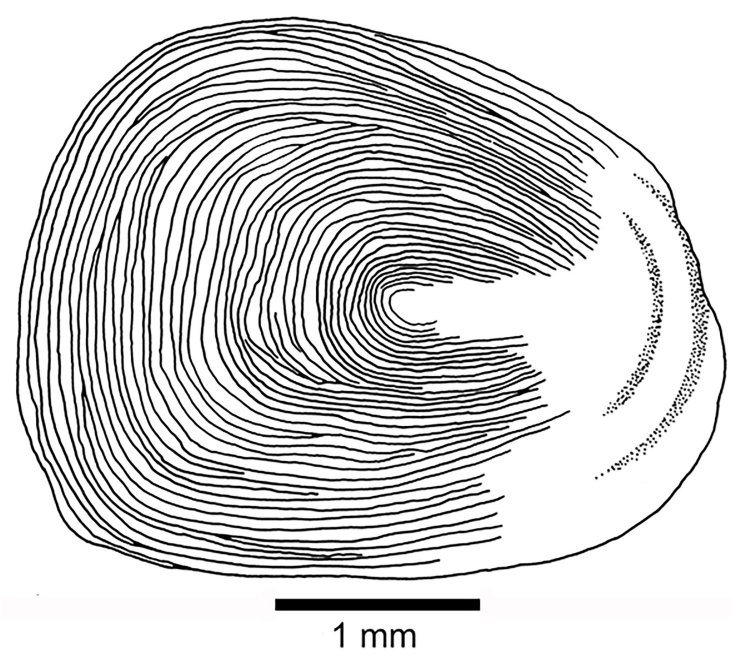

Figure 11. Tharsis elleri n. sp. Cycloid scale from the caudal peduncle of the holotype JME-SOS 08326.

morphies of certain nodes. These assumptions are identified below. Characters supporting nodes are listed in the caption of Fig. 12. Only the nodes representing the branching of the family Ascalaboidae and their support are presented below.

Node $\mathrm{H}$ represents the branching of Tharsis $+($ Ascalabos + Ebertichthys $)$ plus more advanced teleosts and is supported by 16 synapomorphies, three of which are interpreted by the parsimony analysis as uniquely derived: presence of mid-caudal vertebral autocentra thick and sculptured (Ch. 108[2]), walls of mid-caudal centra with cavities for adipose tissue (Ch. 109[2]) and notochord strongly constricted by the walls of the centra (Ch. 110[1]*). Other synapomorphies supporting this node are sutures between all cartilage bones in the braincase retained throughout life (Ch. 22[1]); toothless parasphenoid (Ch. 30[1]); ossified aortic canal present (Ch. 33[1]); canals for occipital arteries in basioccipital bone absent (Ch. 34[1]); spiracular canal absent (Ch. 35[2]); foramen for glossopharyngeal nerve in exoccipital (Ch. 37[1]); no suborbital bone (Ch. 53[3]); one supraorbital bone (Ch. 55[1]); absence of a well-developed protruding lateral bony ridge extending along an elongate dentary that separates dental and splenial regions (Ch. 78[0]); neural spine of preural centrum 2 as long as neural spine of preural centrum 3 (Ch. 142[0]); and epaxial basal fulcra or epaxial procurrent rays in close proximity to neural spines, epurals and posterior uroneurals (Ch. 165 [1]). For other characters supporting this node see caption of Fig. 12.

The Node H1 corresponds to the branching of ((Ascalabos + Ebertichthys) + Tharsis) (family Ascalaboidae) and is supported by three synapomorphies, one of which is interpreted as uniquely derived by the parsimony analysis (Ch. 112[1]): mid-caudal region with diplospondylous centra that become monospondylous throughout ontogeny. Al- though Tharsis elleri n. sp. is coded with a question mark for character 112, the parsimony analysis predicts the presence of diplospondyly in young specimens that become monospondylous during ontogeny. Between the other two characters, one is a reversal: absence of the pelvic axillary process (Ch. 133[0]). Character 135[1] (first dorsal pterygiophore with three or more anteroventral processes, with the first one broadly expanded; Fig. 8) is interpreted as a homoplastic character because this condition is not present in Tharsis dubius. A similar prediction is inferred from the parsimony analysis concerning the absence of a pelvic axillary process for Tharsis elleri $\mathrm{n}$. $\mathrm{sp}$.

Node $\mathrm{H} 2$ corresponds to the branching of Ascalabos and Ebertichthys and is supported by seven characters, three of which are autapomorphies: maxilla with an external row of small conical teeth increasing slightly in size posteriad (Ch. 65[1]), fewer than 40 autocentral vertebrae (Ch. 105[1]), and long epipleurals laterally and markedly oblique to the last ribs and first haemal arches (Ch. 118[1]). The following characters are homoplastic: antorbital branch absent (Ch. 44[1]); ventral cranial region without gular plate (Ch. 103[1]); simple first pectoral fin ray, not fused to fulcra (Ch. 128[0]); and ventral (hypaxial) leading margin of caudal fin with basal fulcra (Ch. 164[0]).

Node H3 represents the genus Tharsis with the branching of (Tharsis dubius and Tharsis elleri $\mathrm{n} \mathrm{sp}$.) and is supported by eight characters, three of which are interpreted as uniquely derived: dorsal margin of caudal fin slightly bent so that both lobes of the fin are slightly asymmetric (Ch. 196[1]), neural spines of the last caudal vertebrae supporting the caudal fin strongly inclined toward the horizontal (Ch. 197[1]; Figs. 9, 10, 13b, 14), and haemal spines of the last caudal vertebrae strongly inclined toward the horizontal (Ch. 198[1]; Figs. 9, 10, 13b, 14). Ch. 168[1] reads as presence of "one or few" fringing fulcra; however, one elongate fringing fulcrum (Figs. 9, 13b, 14) is a feature only found in Tharsis, and consequently, it is interpreted here as uniquely derived for this genus. Characters interpreted as homoplastic are middle pit-line groove (Ch. 41[1]; Figs. 3, 4, 13a) not crossing the pterotic; expanded broad fourth infraorbital bone (Ch. 48[1]); postarticular process of lower jaw poorly developed (Ch. 72[0]); and series of uroneurals at different angles (Ch. 154[1]; Figs. 9, 10, 13b, 14).

In the phylogenetic analysis, the following characters appear as autapomorphies of Tharsis elleri $\mathrm{n}$. sp.: a large, broad infraorbital 4, the largest of the series (Ch. 48[1]) that is larger than in T. dubius (compare Figs. 3, 4 with 13a); a complete sclerotic ring (Figs. 3b, 5) formed by anterior and posterior sclerotic bones (Ch. 56[1]); quadrate-mandibular articulation (Figs. 3, 4) below anterior half of the orbit (Ch. 70[2]); elongate suspensorium due to antero-ventral inclination of the symplectic (Ch. 84[2]); and epaxial rudimentary ray (Fig. 9) present in the caudal fin (Ch. 167[1]).

In the phylogenetic analysis, the following characters are interpreted as autapomorphies of Tharsis dubius: first dorsal 


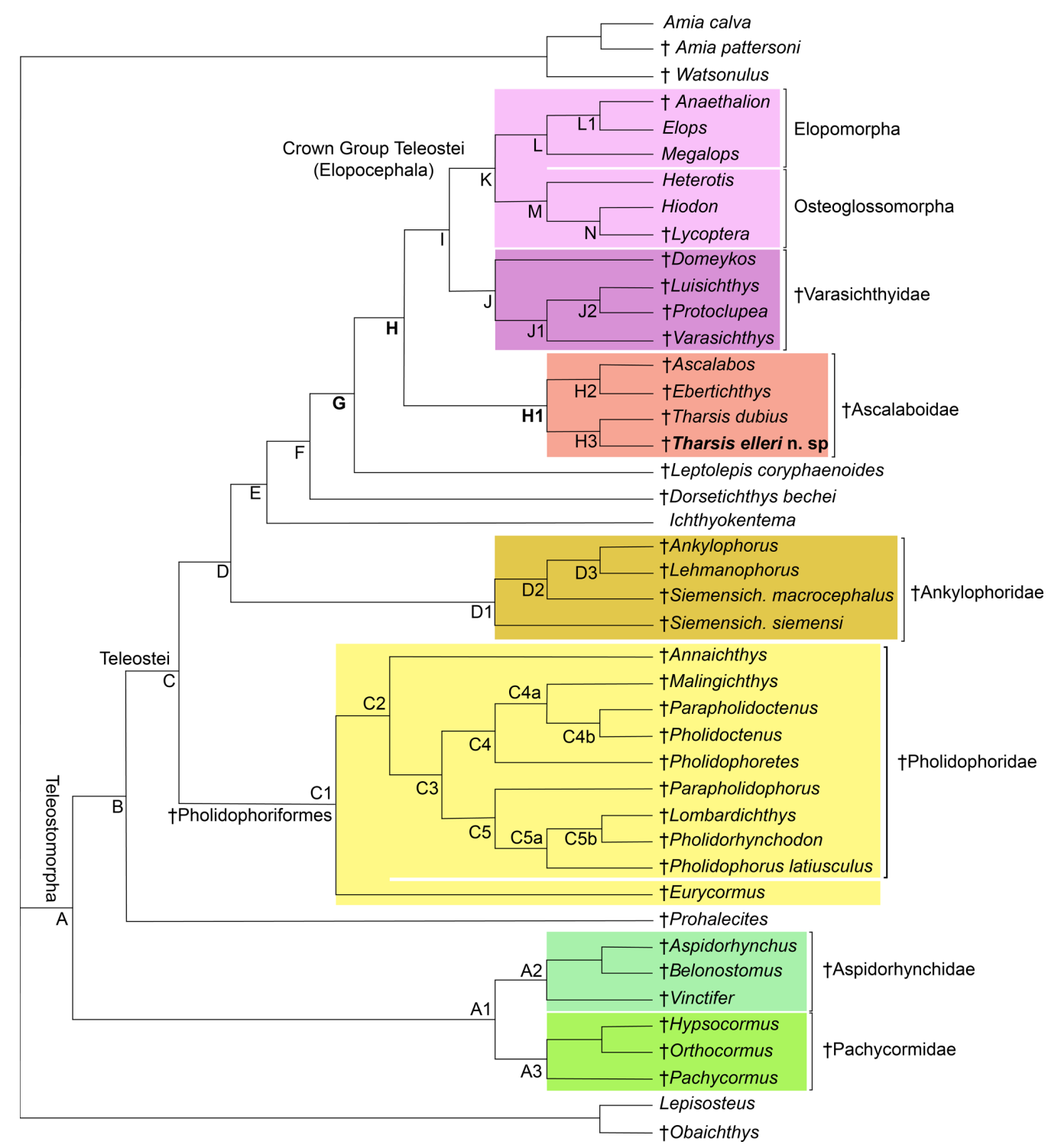

Figure 12. Hypothesis of phylogenetic relationships of the Late Jurassic Ascalabos, Ebertichthys and Tharsis among the most primitive teleosts (Tharsis elleri n. sp. highlighted in bold). Synapomorphies supporting the main nodes are listed below; for a complete list see Arratia (2017: 114-118). Uniquely derived characters are identified with an asterisk (*). See Supplement S1 for descriptions of characters listed below. Node A (Teleosteomorpha or total-group teleost): 13[0]*, 24[1], 29[1], 45[0]*, 56[1], 62[1], 104[0]* , 123[1], 124[1], 128[1], 136[1], 143[1], 145[1], 162[1]* 171[1], 187[1], 190[1]* 191[1]*, 194[1] and 195[1]* . Characters 190-192, 194 and 195 are soft anatomical features that are unknown in fossils, but the parsimony analysis predicts that they were present at this phylogenetic level. Node B: 26[1], 30[1], 39[1], 59[1*], 61[1], 87[1], 89[1], 107[1], 114[1], 126[1], 142[1], 152[1] and 167[1]. Node C (Teleostei- or apomorphy-based group): 3[1], 11[1], 23[2], 53[1], 70[1], 71[1], 73[1], 77[2], 78[1], 115[1], 173[2] and 178[1]. Node C1 (Pholidophoriformes): 2[1], 7[1], 23[1], 124[0], 125[1] $]^{*}, 129[1]$ and 165[1]. Node C2 (Pholidophoridae): 1[1]*, 3[2], 11[0], 20[1], 26[0], 27[1], 77[1], 88[0], 89[0], 111[0], 114[0], 115[0], 133[1], 142[0] and 152[0].Node D: 16[1]*, 86[1]*, 87[2], 91[1], 123[3], 149[1], 151[1], 167[0], 171[0] and 187[0]. Node E: 23[0], 26[0], 30[0], 47[1], 75[1], 76[1]* 127[1], 173[3] and 175[2]. Node F: 11[0], 67[2], 72[1], 74[1]*, 119[1]* and 133[1]. Node G: 8[2], 28[1], $35[1], 56[2], 92[1]^{*}, 107[3]^{*}, 108[1]^{*}, 109[1]^{*}, 116[1]^{*}, 121[1], 122[2], 130[1], 132[1], 138[1], 140[1], 141[1], 144[1], 147[1], 160[1]$, 164[1], 170[2], 174[1]*, 177[1], 180[1], 181[2] and 188[1]. Node H: 22[1], 30[1], 33[1], 34[1], 35[2], 37[1], 53[3], 55[1], 78[0], 108[2]*, $109[2]^{*}, 110[1]^{*}, 142[0], 165[1], 168[2]$ and 176[1]. Node H1 (Ascalaboidae): 112[1]*, 133[0] and 135[1]. Node H2 (Ebertichthys + Ascalabos): 44[1], 65[1]*, 103[1], 105[1]* 118[1]*, 128[0] and 164[0]. Node H3 (Tharsis dubius + Tharsis elleri): 41[1], 48[1], 72[0], 154[1], 168[1], 196[1]*, 197[1]* and 198[1]*. Node I: 36[1], 38[1], 129[1], 161[1], 163[1] and 166[1]. Node J (Varasichthyidae): 94[1]*, 95[1], 120[1], 122[1], 154[1], 167[1], 173[2], 182[1]* and 183[1]*. Node J1: 141[0], 142[1], 144[0] and 146[1]. Node J2: 30[0], 145[0], 152[3], 154[0] and 155[1]. Node K (crown-group Teleostei): 41[1], 71[0], 73[0], 117[1], 134[2]*, 152[3], 156[1], 175[0] and 177[0]. Node L (elopomorphs): 30[0], 57[1] $]^{*}, 62[0], 148[1]^{*}, 153[1], 155[1]$ and 177[2]. Node L1: 70[0], 142[1] and 144[1]. Node M (osteoglossomorphs): $8[0], 36[0], 43[1], 46[1]^{*}, 48[1], 49[1], 55[2], 56[0], 67[1], 83[1]^{*}, 100[1], 103[1], 128[0], 136[0], 143[0], 149[2]$ and 173[0]. Node N: 30[2] and $32[1]^{*}$. 

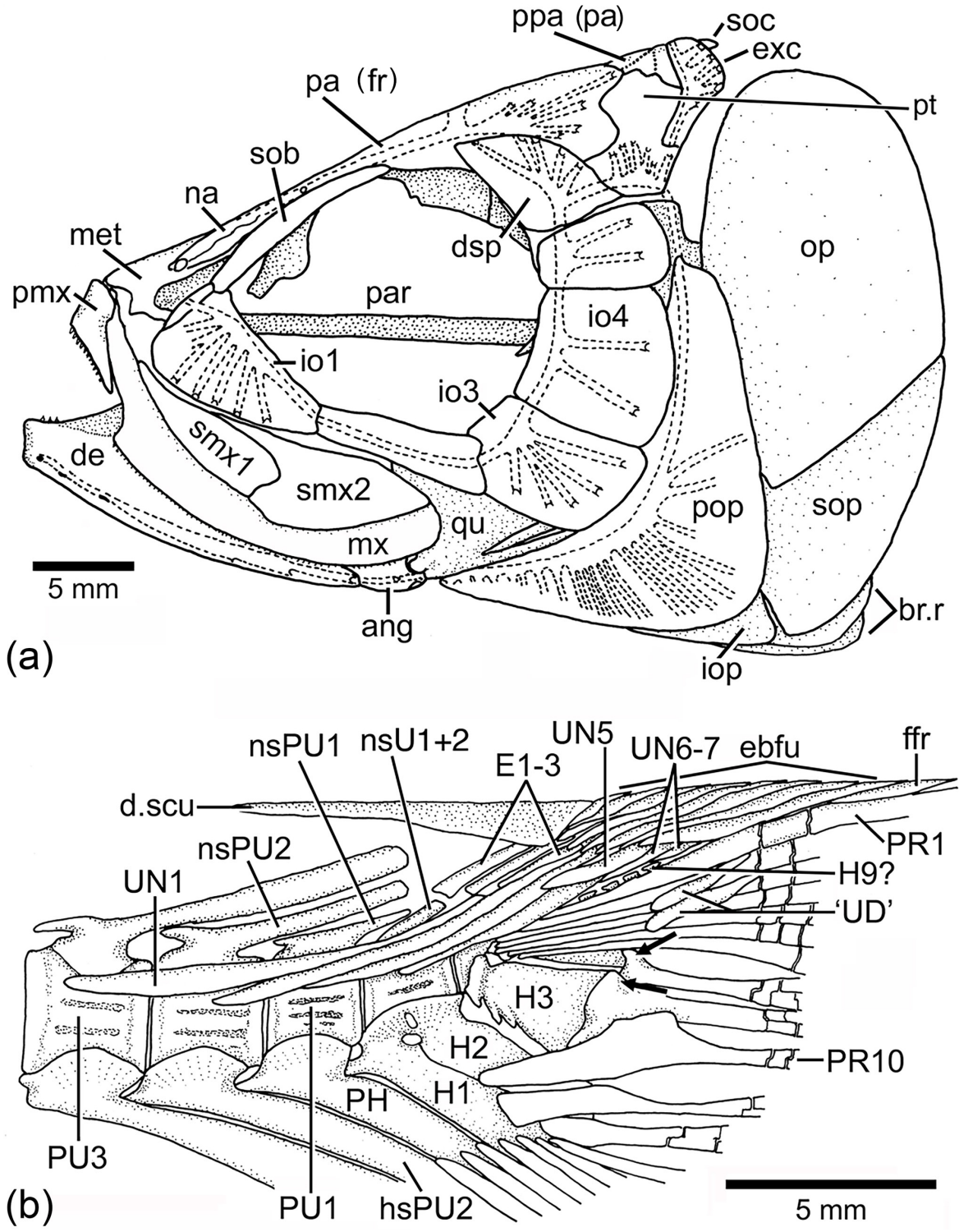

Figure 13. Tharsis dubius in lateral view. (a) Restoration of skull (NHM P.51759). (b) Caudal skeleton (NHM P.927), showing only the proximal region of hypurals interpreted here as 6 to 9. Two black arrows point to the dorsal processes of principal caudal fin rays. Slightly modified from Patterson and Rosen (1977). Abbreviations are as follows: ang, angular; de, dentary; d.scu, dorsal scute; dsp, dermosphenotic; E1-3, epural 1-3; ebfu, epaxial basal fulcra; ffr, fringing fulcrum; H1-3, hypurals 1-3; H9?, hypural 9?; hsPU2, haemal spine of preural centrum 2; io1-4, infraorbitals 1-4; iop, interopercle; met, mesethmoid; mx, maxilla; na, nasal bone; nsPU2, neural spine of preural centrum 2; op, opercle; pa (fr), parietal (frontal); par, parasphenoid; PH, parhypural; pmx, premaxilla; pop, preopercle; ppa (pa), postparietal (parietal); PU4, 1, preural centrum 4, 1; PR1, 10, principal caudal ray 1, 10; pt, pterotic, qu, quadrate; smx1-2, supramaxillae 1-2; sob, supraorbital bone; soc, supraoccipital; sop, subopercle; UN1-7, uroneural 1-7.

pterygiophore lacking a few anterior processes and an enlarged anterior most process $(135[0])$ that is present in other members of Ascalaboidae (Fig. 8; preural vertebrae 3 and 2 (Figs. 13b, 14) with autogenous haemal arches (Ch. 141[0]); neural spine of preural centrum 2 (Figs. 13b, 14) shorter than neural spine of preural centrum 3 (Ch. 142[1]); arch of parhypural (Figs. 13b, 14) not fused with its centrum (Ch. 144[0]); and without hypaxial basal fulcra (Ch. 164[1]).

\section{Discussion}

\subsection{Taxonomic comparison and comments}

Tharsis dubius is known from different localities in the Solnhofen limestone. However, it is difficult to follow the provenance of specimens deposited in different museums where many fishes are simply labeled as from the Solnhofen limestone. In contrast, Tharsis elleri n. sp. is known by 


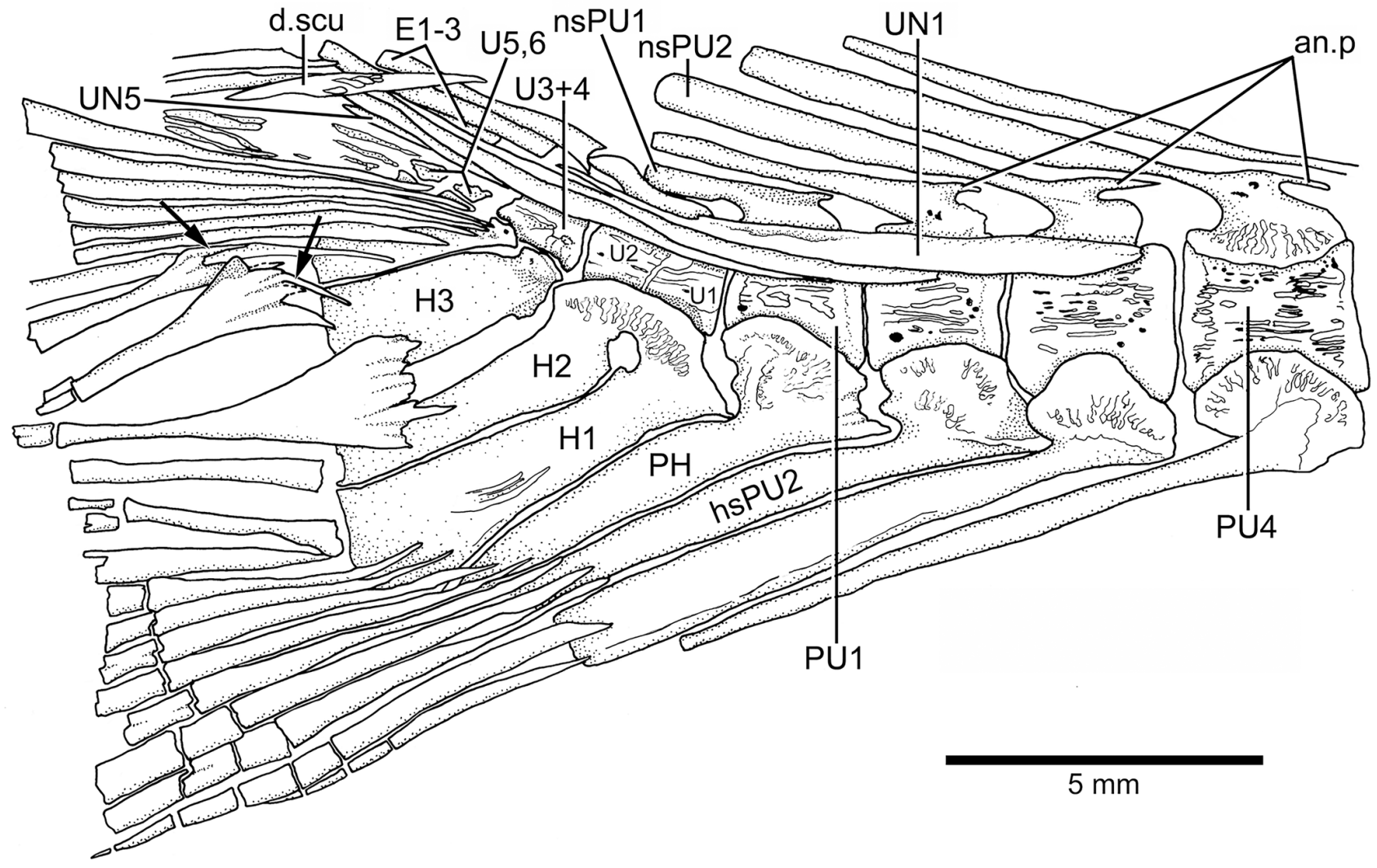

Figure 14. Caudal vertebrae and caudal skeleton of Tharsis dubius (JME-SOS 02633) in lateral view. Note the polyural condition of ural centra U1 to U6. Arrows point to the dorsal processes of caudal fin rays. Note that the dorsal processes have additional elongate processes. Abbreviations are as follows: an.p, anterior process; d.scu, piece of dorsal scute; E1-3, epural 1-3; H1-3, hypurals 1-3; nsPU2, 1, neural spine of preural centrum 2, 1; PH, parhypural; PU4, 1, preural centrum 4, 1; UN1, 5, uroneural 1, 5.

only two specimens from one locality (Wegscheid Quarry in the community of Schernfeld; Fig. 1) in the region of Eichstätt. Few teleostean species like Tharsis dubius are widely distributed, whereas numerous teleostean species are known sometimes from only one locality in Bavaria. For instance, the four species Aspidorhynchus sanzenbacheri (Brito and Ebert, 2009), Bavarichthys incognitus (Arratia and Tischlinger, 2010), Ebertichthys ettlingensis (Arratia, 2016) and Orthogonikleithrus hoelli (Arratia, 1997) are known from one locality, Ettling (Ebert et al., 2015). Similarly, the following four species with a restricted distribution are known mainly from one locality: Eichstaettia mayri from Wintershof and Blumenberg (Arratia, 1987a), Orthocormus roeperi from Brunn (Arratia and Schultze, 2013), and Tischlingerichthys viohli from Mühlheim (Arratia, 1997). It is unclear if the restricted distribution could be a result of sampling or is related to specific environmental conditions in different basins of the Solnhofen limestone or to differences in age among different localities or a combination of factors (Schultze and Arratia, 2009, 2010). In any case, some of the characters present in Tharsis elleri $\mathrm{n}$. sp. are reversals to the plesiomorphic teleostean condition, as for instance, the presence of a complete sclerotic ring with one anterior and one posterior sclerotic bone closely surrounding the eye (Figs. 3b, 5) and the structure of most caudal vertebrae with neural and haemal arches fused to their corresponding centrum (Figs. 2a, 6c, 9, 10).

Among Late Jurassic fishes, Tharsis dubius is recognizable because of its combination of features, including the branching of the cephalic sensory canals, especially in the infraorbital series, preopercle and skull roof bones (Fig. 13a), the vertebral column with autogenous neural and haemal arches (Figs. 13b, 14) in adult individuals, the inclination of the neural and haemal spines of the last caudal region (Figs. 13b, 14), and the special bend of the caudal fin that gives a peculiar aspect to the fish. Despite these identifiable traits, Tharsis has a high morphological variability in specimens from the same locality, as well as through time, as noted by Arratia (1995a) and Arratia and Schultze (2015); this variability and the lack of a type specimen make study of this species difficult. The first historical pictures illustrating Tharsis dubius show a fish with an elongate head, fusiform body, and autogenous neural and haemal arches (see Tischlinger and Viohl, 2015: figs. 59-61), and such details 
agree with the restoration of Leptolepis (Tharsis) dubius by Woodward (1895: p. 510, fig. 15). Since no specific locality was recorded, we can assume that those specimens were recovered in quarries close to Eichstätt. The lack of a typespecimen poses a problem for identification of specimens assigned to Tharsis from other localities, as for instance, Schamhaupten and Daiting (just to mention two localities of different age) that exhibit differences in the presence and absence of pit-line grooves and ethmoidal commissure, skull roof sutures, branching of cephalic sensory canals, structure of the vertebral column, and others (Arratia, 1995a). Thus, the discovery of Tharsis elleri n. sp. from a region where Tharsis dubius is also reported (e.g., Nybelin, 1974 specimen identified as Eichstätt II; see Sect. 2 herein) is not surprising. This is a first step to evaluate the morphology of what we call the Tharsis dubius complex and consequently the discovery of a new species with distinct autapomorphies.

Tharsis dubius and T. elleri n. sp. share numerous morphological characters confirming their taxonomic assignment to the genus Tharsis (see section of Phylogenetic relationships and Fig. 12), for instance, the middle pit-line groove (Ch. 41[1]; Figs. 3, 4, 13a) not crossing the pterotic. Previously, Tharsis dubius was coded as having the pit-line groove crossing the pterotic (e.g., Arratia, 2016, 2017), but since this feature has been observed in only one specimen in the Eichstätt region, the groove is reinterpreted here as absent in the majority of $T$. dubius and coded accordingly. Both species do not have a preopercular process at the posteroventral margin of the hyomandibula contrary to Nybelin (1974). Nybelin (1974: text-figs. 3a-e, 16) described and illustrated the structure that he named "preopercular process" of the hyomandibula in leptolepids and proleptolepids. This process is different in shape and position to the element identified as a preopercular process in Tharsis dubius (see Nybelin 1974, text-fig. 24 and Supplement S1: Figs. S2 and S3). The postcranial skeleton provides several characters supporting the inclusion of the species in the genus Tharsis. For example, the dorsal margin of the caudal fin being slightly inclined posteroventrally so that both lobes of the fin are slightly asymmetrical (Ch. 196[1]) is a feature shared by both species; the presence of neural spines of the last caudal vertebrae supporting the caudal fin strongly inclined toward the horizontal (Ch. 197[1]) and a similar condition is also present by the haemal spines of the last caudal vertebrae (Ch. 198[1]). The presence of one elongate fringing fulcrum (Ch. 168[1]) and the presence of uroneurals distributed in two sets, the elongate first four and the short one to three posterior uroneurals positioned at the distal portion of the anterior set are also shared by both species. Both species have two conspicuous, elongate urodermals lying on the lateral surface of the first two principal caudal rays (Ch. 177[1]; in contrast to urodermals, the uroneurals are internal structures with their posterior ends covered by epaxial basal fulcra or procurrent rays and the bases of the first principal caudal rays). There are several features that remain incompletely known for the new species due to incomplete preservation, e.g., the total number of branchiostegal rays and fin rays and their support. For more comments on specific characters of Tharsis see Supplement S1.

This contribution, as well as previous studies on Late Jurassic fishes, has not included specimens that were assigned to Leptolepis (Tharsis) voithii from Cerin, France, by Saint-Seine in 1949 (in part according to Nybelin, 1974). A revision of the specimens from Cerin is suggested. A revision of the Tharsis dubius complex from different localities in the Solnhofen limestone, and from different ages, is suggested to understand if $T$. dubius is one species with a broad distribution throughout time and space or is a poorly understood diversified species group.

\subsection{Phylogenetic position of Tharsis}

Several genera of Late Jurassic age from the Solnhofen limestone are known by single species such as Tharsis, a situation that now changes after the discovery of Tharsis elleri $\mathrm{n}$. sp. Previously, and following the tradition of the time, Tharsis was assigned to the family Leptolepididae (e.g., Agassiz, 1843; Woodward, 1895) until Nybelin (1974) removed Leptolepis dubius from the genus Leptolepis and assigned it to the new genus Tharsis within the family Leptolepididae. However, this interpretation changed with novel studies concerning teleostean phylogenetic relationships using the methodology of Hennig (1966). For instance, the first phylogenetic hypotheses proposed Leptolepis coryphaenoides and Tharsis dubius occupying different positions, with $L$. coryphaenoides more primitive than Tharsis that is closer to more advanced teleosts (Patterson, 1977; Patterson and Rosen, 1977; Fig. 12 herein). Similar results were also reached in a study of the caudal skeletons of some fossil and extant teleosts (Arratia, 1991). Consequently, Tharsis was removed from Leptolepididae and left as incertae sedis among Teleostei (see Arratia, 1997, 1999, 2000, 2013).

Recent studies concerning Late Jurassic teleosts, especially of the new genus Ebertichthys and the revision of Ascalabos, proposed the two genera as members of a new family, Ascalaboidae (Arratia, 2016). Later, Tharsis dubius (based mainly on specimens from Eichstätt and Zandt areas in Bavaria) was added to the family (Arratia, 2017), a result that is confirmed here. Furthermore, the present results show that the branching of the teleostean node Ascalaboidae plus more advanced teleosts (Fig. 12: Node H) has strong support based on at least 16 synapomorphies. Furthermore, the node of Leptolepis coryphaenoides plus more advanced teleosts (Fig. 12: Node G) has increased its support to 26 synapomorphies. Consequently, the addition of Tharsis elleri $\mathrm{n}$. sp. and the change of coding in two characters of $T$. dubius have an impact on the distribution of characters of primitive teleosts. For instance, the polytomy formed by Ankylophoridae, Ichthyokentem and Dorsetichthys plus more advanced teleosts in Arratia (2017: fig. 9) is now resolved. Conversely, 
this is not surprising because, as shown in previous studies, the deletion or addition of Tharsis dubius to a phylogenetic analysis has dramatic effects on the topology of the tree (see Arratia, 1995b, 1997, 1999). This could be explained by the accumulation of synapomorphies supporting the level of Ascalaboidea plus more advanced teleosts (Fig. 12: Node H) that are important in the understanding of the evolution of more advanced teleosts, including the crown Teleostei.

In summary, based on the available morphological information of specimens assigned to Tharsis, there is no support for an interpretation that these fishes are part of the Leptolepididae, especially if we consider the advanced pattern of the braincase and vertebral column that Tharsis shares with more advanced teleosts compared to leptolepids and more primitive teleosts (compare characters supporting Nodes $\mathrm{G}$ and $\mathrm{H}$ in Fig. 12).

Data availability. All available data are included in the paper and in Supplement 1 (list of characters used in the phylogenetic analysis) and 2 (matrix with coding of characters).

Supplement. The supplement related to this article is available online at: https://doi.org/10.5194/fr-22-1-2019-supplement.

Author contributions. This contribution resulted from the combination of expertise of the three co-authors. Descriptions as well as the general organization of the paper are mainly the responsibility of GA. Photographs are the responsibility of HT. Literature, especially old and recent articles, was searched by HPS. The co-authors equally participated in checking, rewriting, revising, and providing changes and improvements through the whole process of preparation of the paper, including the revision of the proofs.

Competing interests. The authors declare that they have no conflict of interest.

Acknowledgements. We thank the following individuals and institutions for permission to study material under their care: David Berman (CM); Hans Bjerring (SMNH); Martina Kölbl-Ebert and Günter Viohl (JME); Alison Longbottom and the late Colin Patterson (NHM). The senior author thanks especially Uwe Eller (Dümpelfeld) and the late Helmut Leich (Bochum) for permission to study some specimens belonging to their collections. Thanks to the following individuals and institutions for permission to study specimens included in the phylogenetic analysis: David Berman (CM); Hans Bjerring (SMNH); Ronald Böttcher (SMNS); Donald Butt (UCLA); Curt H. von Daniels (BGHan); William Eschmeyer and David Catania (CAS); William L. Fink and Douglas Nelson (UMMZ, Ann Arbor, Michigan); Heinz Furrer (PIMUZ, Zürich, Switzerland); Ursula Göhlich (NHMW); Lance Grande, William Simpson, Mark Westneat, and Mary Ann Rogers (FMNH); Hans Jahnke (GOE); Martina Kölbl-Ebert and Günter Viohl (JME); the late Karel Liem, Karsten Hartel, the late Farrish Jenkins, and Jessica Cundiff (MCZ); Marc Louette and the late Guy Teugels (MRAC); Douglas Markle (OS); the late Larry Martin and Desui Miao (KUVP); John D. McEacharan and Michael E. Retzer (TCWC); Wolfgang Mette and Werner Resch (Innsbruck); Anna Paganoni (MCSNB): Lynne Parenti and Jeffrey Williams (USNM): the late Colin Patterson and Alison Longbottom (NHM): Robert Robins (UF, Gainesville, Florida); Martin Röper (BMM-S, Solnhofen); Richard Rosenblatt (SIO); William Saul (ANSP): Frank J. Schwartz (UNC); Andrew Simons and M. Vincent Hirt (JFBM, Minneapolis, Minnesota); Don Stacey and Erling Holm (ROM); James Stewart (formerly at LACM); Melanie Stiassny and Barbara Brown (AMNH); Richard Stucky (DMNH); Andrea Tintori (University of Milan, Italy); Peter Wellnhofer, Oliver W. M. Rauhut and Markus Moser (BSPG); Frank Westphal and the late Rolf-Ernst Reif (GPIT); Florian Witzmann (MB); Edward O. Wiley and Andrew Bentley (KUNHM); Jiang-Yong Zhang and Min Zhu (IVVP); and Irene Zorn (GBA). Martin Ebert (JME) helped with photographs and has been especially helpful to G. Arratia during her study visits to the collections of the Jura-Museum. Terry J. Meehan prepared the electronic submission of all figures and revised the style of the manuscript and Kelli Sturm helped editing Supplement 2. Our special thanks to Eric Hilton (Gloucester Point, United States) and Jürgen Kriwet (Vienna, Austria) for reviewing the manuscript.

Edited by: Florian Witzmann

Reviewed by: Eric Hilton and Juergen Kriwet

\section{References}

Agassiz, L.: Recherches sur les Poissons Fossiles, 5 vols., Petitpierre, Neuchâtel and Soleure, XCVII + 1798 pp., 1833-1843.

Arratia, G.: Anaethalion and similar teleosts (Actinopterygii, Pisces) from the Late Jurassic (Tithonian) of southern Germany and their relationships, Palaeontogr. Abt. A, 200, 1-44, 1987a.

Arratia, G.: Orthogonikleithrus leichi n. gen., n. sp. (Pisces: Teleostei) from the Late Jurassic of Germany, Palaeontol. Z., 61, 309-320, 1987b.

Arratia, G.: The caudal skeleton of Jurassic teleosts: A phylogenetic analysis, in: Early Vertebrates and Related Problems in Evolutionary Biology, edited by: Chang, M.-M., Liu, Y.-H., and Zhang, G.-R., Science Press, Beijing, 249-340, 1991.

Arratia, G.: Temporal sequence and morphological variation in Jurassic fishes of southern Germany, in: II. International Symposium on Lithographic Limestones, Cuenca, Extended Abstracts, Ediciones Universidad Autónoma, Madrid, 15-18, 1995a.

Arratia, G.: Importance of specific fossils in teleostean phylogeny, Geobios, Mém. Spec., 19, 173-176, 1995b.

Arratia, G.: Basal teleosts and teleostean phylogeny, Palaeo Ichthyologica, 7, 1-168, 1997.

Arratia, G.: The monophyly of Teleostei and stem group teleosts, in: Mesozoic Fishes - Systematics and Fossil Record, edited by: Arratia, G. and Schultze, H.-P., Verlag Dr. F. Pfeil, München, 265-334, 1999.

Arratia, G.: Remarkable teleostean fishes from the Late Jurassic of southern Germany and their phylogenetic relationships, Foss. 
Rec., 3, 137-179, https://doi.org/10.1002/mmng.20000030108, 2000.

Arratia, G.: Actinopterygian postcranial skeleton with special reference to the diversity of fin ray elements, and the problem of identifying homologies, in: Mesozoic Fishes 4 - Homology and Phylogeny, edited by: Arratia, G., Schultze, H.-P., and Wilson, M. V. H., Verlag. Dr. F. Pfeil, München, 40-101, 2008.

Arratia, G.: Identifying patterns of diversity of the actinopterygian fulcra, Acta Zool.-Stockholm, 90, 220-235, 2009.

Arratia, G.: Morphology, taxonomy, and phylogeny of Triassic pholidophorid fishes (Actinopterygii, Teleostei), J. Vertebr. Paleontol., 33, 1-138, 2013.

Arratia, G.: Complexities of Early Teleostei and the Evolution of Particular Morphological Structures through Time, Copeia, 103, 999-1025, 2015.

Arratia, G.: New remarkable Late Jurassic teleosts from southern Germany: Ascalaboidae n. fam., its content, morphology, and phylogenetic relationships, Foss. Rec., 19, 31-59, https://doi.org/10.5194/fr-19-31-2016, 2016.

Arratia, G.: New Triassic teleosts (Actinopterygii, Teleosteomorpha) from northern Italy and their phylogenetic relationships among the most basal teleosts, J. Vertebr. Paleontol., 37, e1312690, https://doi.org/10.1080/02724634.2017.1312690, 2017.

Arratia, G. and Lambers, P.: The caudal skeleton of pachycormiform fishes: Parallel evolution? in: Mesozoic Fishes - Systematics and Paleoecology, edited by: Arratia, G. and Viohl, G., Verlag Dr. F. Pfeil, München, 219-241, 1996.

Arratia, G. and Schultze, H.-P.: Reevaluation of the caudal skeleton of certain actinopterygian fishes. III. Salmonidae. Homologization of caudal skeletal structures, J. Morphol., 214, 1-63, 1992.

Arratia, G. and Schultze, H.-P.: Outstanding features of a new Late Jurassic pachycormiform fish from the Kimmeridgian of Brunn, Germany and comments on current understanding of pachycormiforms, in: Mesozoic Fishes 5 - Global Diversity and Evolution, edited by: Arratia, G., Schultze, H.-P., and Wilson M. V. H., Verlag Dr. F. Pfeil, München, 87-120, 2013.

Arratia, G. and Schultze, H.-P.: Knochenfische i.e.S. (Teleostei), in: Solnhofen, ein Fenster in die Jurazeit, edited by: Arratia, G., Schultze, H.-P., Tischlinger, H., and Viohl, G., Verlag Dr. F. Pfeil, München, 2, 389-409, 2015.

Arratia, G. and Tischlinger, H.: The first record of Late Jurassic crossognathiform fishes from Europe and their phylogenetic importance for teleostean phylogeny, Foss. Rec., 13, 317-341, https://doi.org/10.1002/mmng.201000005, 2010.

Arratia, G., Schultze, H.-P., and Casciotta, J. R.: Vertebral column and associated elements in dipnoans and comparison with other fishes. Development and homology, J. Morphol., 250, 101-172, 2001.

Baier, J. J.: Monumenta rerum petrificatarum praeciia Oryctographia Noricae supplementi loco jungenda interprete fillo Ferdinando Iacobo Baiero, Supplement volume of F. J. Baier (Ed.), Lichtensteger, Nürnberg, 20 pp., 1757.

Besler, B.: Fasciculus rariorum at aspectu dignorum varii generis quae collegit et suis impensis aeri ad vivum incidi curavit atque evulgavit, Noriberg, Nürnberg, 48 pp., 1616.

Blainville, H. D. de: Sur les ichthyolites ou les poissons fossiles, Nouveau Dictionnaire d'Histoire Naturelle, Nouvelle Édition, 27, 310-395, 1818.
Brito, P. M. and Ebert, M.: A new aspidorhynchid fish (Teleostei: Aspidorhynchiformes) from the Upper Jurassic of Ettling, Solnhofen, Bavaria, Germany, Comtes Rendues Paleosol, 8, 395-402, 2009.

Cope, E. D.: Geology and Paleontology General Notes, Zittel's Manual of Palaeontology, Am. Nat., 21, 1014-1019, 1887.

Ebert, M., Kölbl-Ebert, M., and Lane, J. A.: Fauna and predator-prey relationships of Ettling, an actinopterygian fish-dominated Konservat-Lagerstätte from the Late Jurassic of southern Germany, PLoS ONE, 10, e0116140, https://doi.org/10.1371/journal.pone.0116140, 2015.

Giebel, C. G.: Fauna der Vorwelt, mit steter Berücksichtigung der lebenden Tiere, Erster Band: Wirbelthiere, Dritte Abtheilung: Fische, Brockhaus, Leipzig, 1-467, 1848.

Harder, W.: Anatomy of fishes. Part I Text, XII + 612 pp., Part II Figures and Plates, 1-132+ 13 plates, E. Schweizerbart'sche Verlagsbuchhandlung, Stuttgart, 1975.

Hennig, W.: Phylogenetic systematics, University of Illinois Press, Urbana, III + 263 pp., 1966.

Jollie, M.: Chordate Morphology, Reinhold Publishing Co., New York, XIV + 478 pp., 1962.

Knorr, G. W.: Sammlung von Merckwürdigkeiten der Natur und Alterthümern des Erdbodens welche petreficirte Cörper enthält, Thl. I, 1, Abschnitt, A. Bieling, Nürnberg, 1-187, 1755.

Müller, J.: Über den Bau und die Grenzen der Ganoiden, und über das natürliche System der Fische, Physikalisch-Mathematische Abhandlungen der königlichen Akademie der Wissenschaften zu Berlin, 1845, 117-216, 1845.

Münster, G. Graf zu: Mittheilungen, an Professor Bronn gerichtet, Neues Jahrbuch für Mineralogie, Geognosie, Geologie und Petrefaktenkunde, 1834, 538-542, 1834.

Münster, G. Graf zu: Über einige Versteinerungen in den lithographischen Schiefern von Solnhofen, Neues Jahrbuch für Mineralogie, Geognosie, Geologie und Petrefaktenkunde, 1839, 677-682, 1839a.

Münster, G. Graf zu: Ascalabos voithii, Beiträge zur PetrefactenKunde, 2, 112-114, 1839b.

Münster, G. Graf zu: Beiträge zur Kenntniss einiger neuen seltenen Versteinerungen aus den lithographischen Schiefern in Baiern, Neues Jahrbuch für Mineralogie, Geognosie, Geologie und Petrefaktenkunde, 1842, 35-64, 1842.

Niebuhr, B. and Pürner, T.: Plattenkalk und Frankendolomit - Lithostratigraphie der Weißjura-Gruppe der Frankenalb (außeralpiner Oberjura, Bayern), Schriftenreihe der Deutschen Gesellschaft für Geowissenschaften, 83, 5-71, 2014.

Nybelin, O.: Zur Morphologie und Terminologie des Schwanzskelettes der Actinopterygier, Ark. Zool., 15, 485516, 1963.

Nybelin, O.: Versuch einer taxonomischen Revision der jurassischen Fisch-Gattung Thrissops Agassiz, Göteborgs kungliga vetenskaps- och vitterhets Samhälles Handligar, Series B, 9, 144, 1964.

Nybelin, O.: Versuch einer taxonomischen Revision der Anaethalion-Arten des Weissjura Deutschlands, Acta Regiae Societatis Scientiarum et Litterarum Gothoburgensis, Zoologica, 2, 1-53, 1967.

Nybelin, O.: A revision of the leptolepid fishes, Acta Regiae Societatis Scientiarum et Litterarum Gothoburgensis, Zoologica, 9, 1-202, 1974. 
Patterson, C.: Interrelationships of holosteans, in: Interrelationships of Fishes, edited by: Greenwood, P. H., Miles, R. S., and Patterson, C., Zoological Journal of Linnean Society, 53, 233-305, 1973.

Patterson, C.: The braincase of pholidophorid and leptolepid fishes, with a review of the actinopterygian braincase, Philos. T Roy. Soc. B, 269, 275-579, 1975.

Patterson, C.: Contributions of Paleontology to Teleostean phylogeny, in: Major Patterns in Vertebrate evolution, edited by: Hecht, M. K., Goody, P. C., and Hecht, B. M., NATO Advances Study Institute Series, Serie A, 579-643, 1977.

Patterson, C. and Rosen, D. E.: Review of ichthyodectiform and other Mesozoic teleost fishes and the theory and practice of classifying fossils, B. Am. Mus. Nat. Hist., 158, 81-172, 1977.

Saint-Seine, P. de: Les poissons des calcaires lithographiques de Cerin (Ain), Nouvelle Archive du Muséum d'Histoire naturelle, Lyon, 2, 1-357, 1949.

Schultze, H.-P.: Morphologische und histologische Untersuchungen an den Schuppen mesozoischer Actinopterygier (Übergang von Ganoid- zu Rundschuppen), Neues Jahrb. Geol. P.-A., 126, 232312, 1966.

Schultze, H.-P.: The scales of Mesozoic actinopterygians, in: Mesozoic Fishes - Systematics and Paleoecology, edited by: Arratia, G. and Viohl, G., Verlag Dr. F. Pfeil, München, 83-93, 1996.

Schultze, H.-P.: Nomenclature and homologization of cranial bones in actinopterygians, in: Mesozoic Fishes 4 - Homology and Phylogeny, edited by: Arratia, G., Schultze, H.-P., and Wilson, M. V. H., Verlag Dr. F. Pfeil, München, 23-48, 2008.

Schultze, H.-P.: Liste der Fossilien, in: Solnhofen, ein Fenster in die Jurazeit, edited by: Arratia, G., Schultze, H.-P., Tischlinger, H., and Viohl, G., Verlag Dr. F. Pfeil, München, 560-672, 2015.

Schultze, H.-P. and Arratia, G.: Reevaluation of the caudal skeleton of some actinopterygian fishes. II. Hiodon, Elops and Albula, J. Morphol., 195, 257-303, 1988.

Schultze, H.-P. and Arratia, G.: The composition of the caudal skeleton of teleosts (Actinopterygii, Osteichthyes), Zool. J. Linn. Soc.-Lond., 97, 189-231, 1989.

Schultze, H.-P. and Arratia, G.: The basins of the Lithographic Limestone of Southern Germany and the rise of new life: fish groups, 5. International Symposium on Lithographic Limestone and Plattenkalk, Naturhistorisches Museum Basel, Switzerland, 17.-22.8.2009. Abstracts and Field Guides, Actes 2009 bis, Societé Jurassienne d'émulation, 73-75, 2009.

Schultze, H.-P. and Arratia, G.: The basins of the Lithographic Limestone of southern Germany and the rise of new fish groups, Fifth International Meeting on Mesozoic Fishes, Global Diversity and Evolution, Saltillo, México, 1-7 August 2010, Abstract Book, 80, 2010.
Schultze, H.-P. and Arratia, G.: The caudal skeleton of basal teleosts, its conventions, and some of its major evolutionary novelties in a temporal dimension, in: Mesozoic Fishes 5 - Global Diversity and Evolution, edited by: Arratia, G., Schultze, H.-P., and Wilson, M. V. H., Verlag Dr. F. Pfeil, München, 187-246, 2013.

Schweigert, G.: Biostratigraphie der Plattenkalke der südlichen Frankenalb, in: Solnhofen, Fenster in die Jurazeit, edited by: Arratia, G., Schultze, H.-P., Tischlinger, H., and Viohl, G., Verlag Dr. F. Pfeil, München, 1, 63-66, 2015.

Swofford, D. L.: PAUP*: Phylogenetic Analysis Using Parsimony (*and other methods), Version 4.0 Beta, Sinauer Associates, Sunderland, Massachusetts, 2000.

Tischlinger, H.: Arbeiten mit ultraviolettem Licht, in: Solnhofen, ein Fenster in die Jurazeit, edited by: Arratia, G., Schultze, H.-P., Tischlinger, H., and Viohl, G., Verlag Dr. F. Pfeil, München, 1, 109-113, 2015.

Tischlinger, H. and Arratia, G.: Ultraviolet light as a tool of investigating Mesozoic fishes with a focus on the ichthyofauna of the Solnhofen Limestone, in Mesozoic Fishes 5 - Global Diversity and Evolution, edited by: Arratia, G., Schultze, H.-P., and Wilson, W. V. M., Verlag Dr. F. Pfeil, München, 549-560, 2013.

Tischlinger, H. and Viohl, G.: Sammler, Sammlungen, und Forscher, in: Solnhofen, ein Fenster in die Jurazeit, edited by: Arratia, G., Schultze, H.-P., Tischlinger, H., and Viohl, G., Verlag Dr. F. Pfeil, München, 1, 41-54, 2015.

Vetter, B.: Die Fische aus dem lithographischen Schiefer im Dresdener Museum, Mittheilungen aus dem königlich mineralogischgeologischen und praehistorischen Museum in Dresden, 4, 1118, 1881.

Viohl, G.: The paleoenvironment of the Late Jurassic fishes from the Southern Franconian Alb (Bavaria, Germany), in: Mesozoic Fishes - Systematics and Paleoecology, edited by: Arratia, G. and Viohl, G., Verlag Dr. F. Pfeil, München, 513-528, 1996.

Wagner, J. A.: Vergleichung der urweltlichen Fauna des lithographischen Schiefers von Cerin mit den gleichnamigen Ablagerungen im fränkischen Jura, Gelehrter Anzeiger der königlich bayerischen Akademie der Wissenschaften, 48, 390-412, 1861.

Wagner, J. A.: Monographie der fossilen Fische aus den lithographischen Schiefern Bayerns, Zweite Abtheilung, Abhandlungen der königlich bayerischen Akademie der Wissenschaften, mathematisch-physikalische Klasse, 9, 612-748, 1863.

Westoll, T. S.: The origin of the tetrapods, Biol. Rev., 18, 78-98, 1943.

Woodward, A. S.: Catalogue of the Fossil Fishes in the British Museum (Natural History). Part III, 1-544, Trustees of the British Museum of Natural History, London, 1895. 